\title{
Impact of Relationship between Organizational Silence and Organizational Commitment on Social Responsibility
}

Ahmad Keykha ${ }^{1}$ Ph.D Student of Economics and Financial Management of Higher Education, Department of Educational Management and Planning, Faculty of Education and Psychology, Tehran University, Iran (Corresponding Author).

Seyyed Mohammad Mirkamali² ${ }^{2}$ Professor, Department of Educational Management and Planning, Faculty of Education and Psychology, Tehran University, Iran.

Bahador Ebrahimi ${ }^{3}$ M.A. in Accounting, Department of Accounting, Facultyof Management and Accounting, Allameh Tabatabaee University, Tehran, Iran.

\begin{abstract}
Universities, as a driving force in any country, play a key role in achieving various aspects of development. The most important asset and competitive advantage of any organization are its human resources. University employees, too, play a striking and influential role in the quality of the performance of their organization. Therefore, it is very important to address issues related to employees' performance. The aim of this study was to explain the relationships between organizational silence and organizational commitment and their effect on employees' social responsibility. Data were gathered through questionnaires distributed among 132 employees and were analyzed by structural equation technique. The results show that organizational silence has a positive and significant effect on social responsibility. Social responsibility has a positive and significant effect on organizational commitment. Also, results confirm the negative and significant effect of organizational silence variable on organizational commitment through the mediating variable of social responsibility. Finally, suggestions have been made for executives and researchers.
\end{abstract}

Keywords: Organizational Silence; Organizational Commitment; Accountability; Higher Education; University.

1.ahmadkeykha@ut.ac.ir

2.mkamali@ut.ac.ir

3. bahadorebrahimi@atu.ac.ir 


\section{مقام}

اهميت عامل انسانى و نقش منحصر به فرد آن به منزله يك منبع راهبردى، جايياهى به مراتب بالاتر از كذشته يافته است، تا جايى كه در تفكر سازمانى ييشرفته از انسان به مثابه مهمرترين دارايى براى سازمان ياد مىشود (اناركى اردكانى و همكاران، Vوس()). در واقع، ثروت هر سازمانى منابع انسانى است كه در بهبود عملكرد سازمان ها نقش كليدى دارند (Karaca, 2013; Pohjola, 2001). در دنياى امروزى، مزيت رقابتى سازمانها در گرو سرمايههاى انسانى و كاركنانى است كه با كارشان عجين مىشوند و دستيابى به اهداف سازمانى را با تحقق اهداف فردى خود يكى مى مدانند

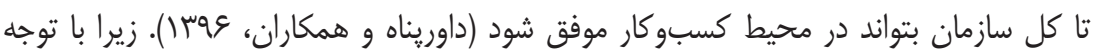
به متنوعتر شدن محيطهاى بيرونى سازمانهاى مدرن، و يِيجيدهتر و تعاملىتر شدن محيطهاى درونى سازمانها كاركنان به عنوان يك منبع غنى بازخورد براى حل مسائل مربوط به سازمان محسوب مىشوند (Detert \& Burris, 2007). از همين رو، جنَ واقعى كشورها در دهلهاى آينده نه بر سر انرزى و نه بر سر بازارها، بلكه براى سرمايههاى انسانى است. بنابراين، كشورها

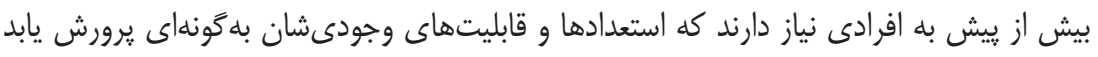
كه از دانش، تخصص، مهارت و از همه مهمتر، توانايى تفكر خلاق خوبى برخوردار باشند (اعرابى و موسوى، MMr (). اين مسئله بdطور فزايندهاى براى كشورهاى درحالتوسعه كه قصد دارند اقتصاد

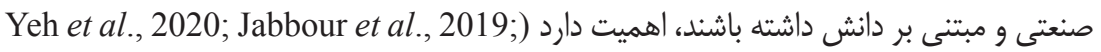
Kang et al., 2018; Tan et al., 2012 و سازمانها، مديريت موثر منابع انسانى دانا و تواناست. انسان تنها عنصر داراى شعورى است كه به عنوان هماهنگ كننده ساير عوامل سازمانى، نقش اصلى در ميان كليه عوامل بر عهلده دارد، و بدون افراد كارامد، دستيابى به اهداف سازمانى غيرممكن است (رضايىمنش و بارانى، بوسا). دانشگًاهها به عنوان مركزى اصلى توسعه كشورها در زيستبومهاى گَوناگون، بلويثه در كشورهاى درحالتوسعه همجون ايران نقش اساسى بر عهده دارند. با نخاهى به اسناد بالادستى

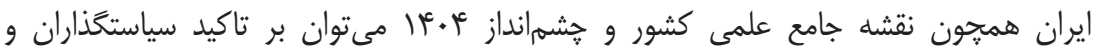
برناملريزان در استفاده از نمادهاى دانشگاهى براى دستيابى به اهداف توسعه كشور يى برد.

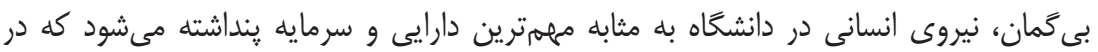


راهبرى دانشخاه به سمت نقطه مطلوب نقشآفرينى كليدى دارد. از سوى ديخر، بسيارى از

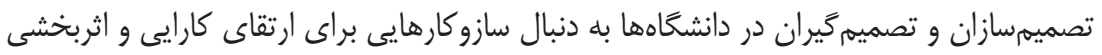

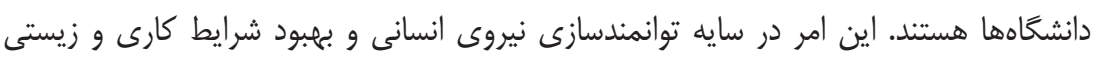

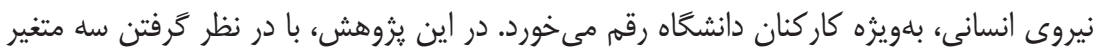

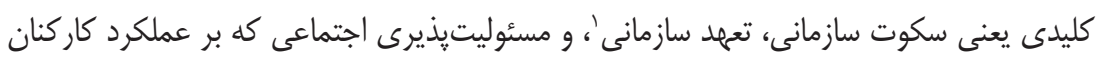

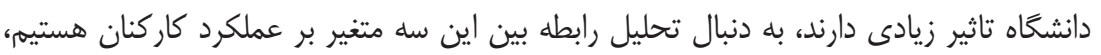

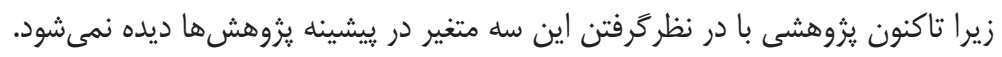

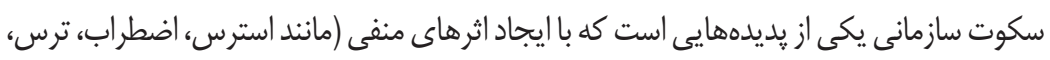

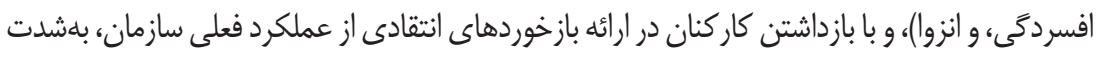
عملكرد كار كنان را متاثر مىسازد و باعث فرسايش سرمايه انسانى (كاركنان) در سازمان (دانشكاناه)

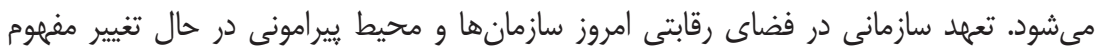

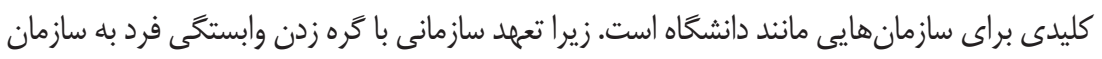

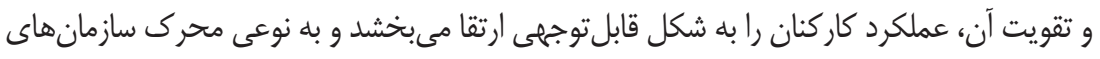

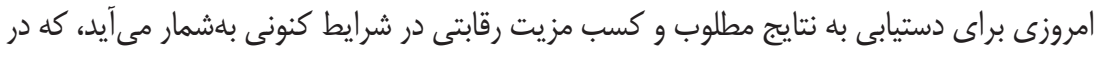

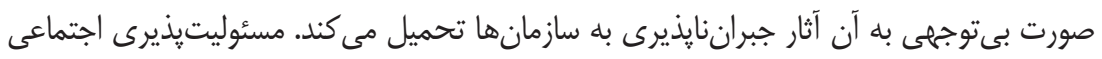

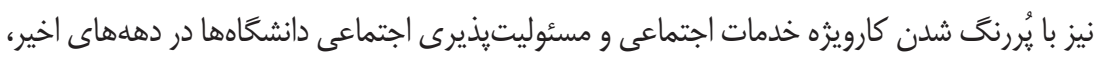

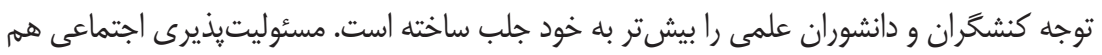

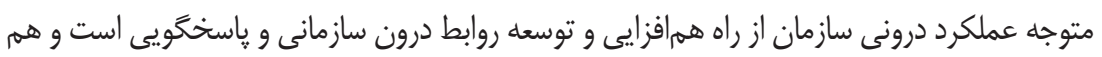

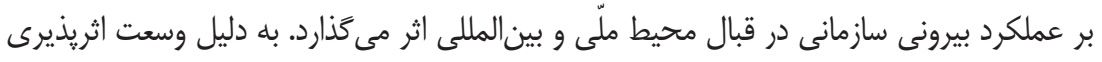

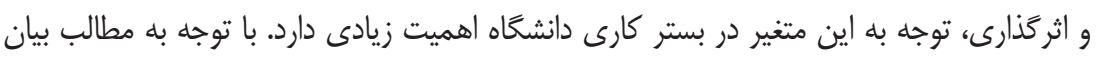

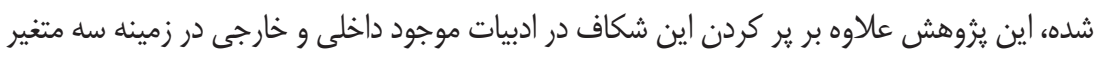

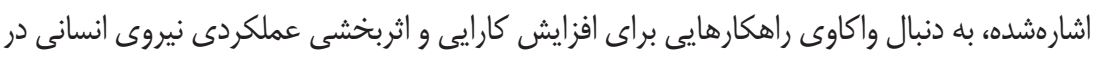
دانشگاه براى سرعتبخشى در دستيابى به اهداف ترسيمشده بـ آن است.

1. Organizational Commitment 


\section{مبانى نظرى يزوهش}

سازمان دانشخاه به عنوان كانون عالىترين ييشرفتهاى علمى در همه زمينههاست كه موجب اعتلاى علم و دانش در جامعه مىشود. بىترديد سرمايههاى دانشى براى هر سازمانى رمز

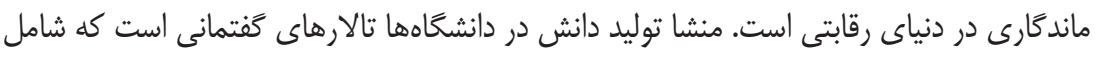

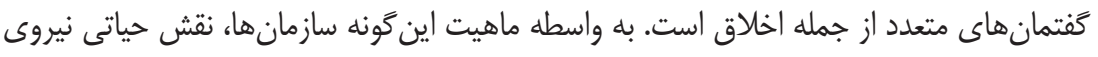

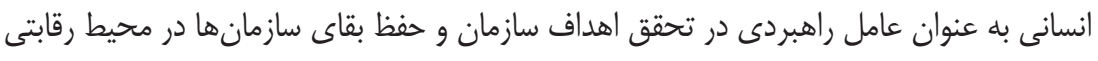

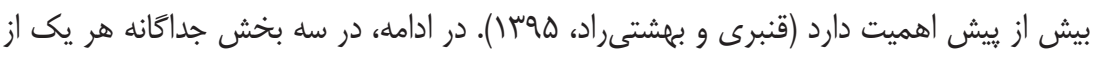
متغيرهاى مورد مطالعه تشريح مىشوند.

\section{سكوت سازمانى}

يديدهسكوت كار كنان،|غلبسازمان هار افراكرفتهاست، إماهنوزبررسى علمى كمى دربارهسكوت كار كنان

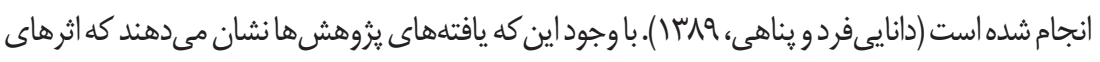

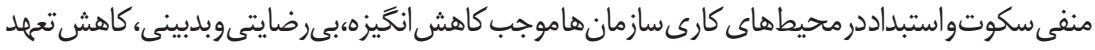

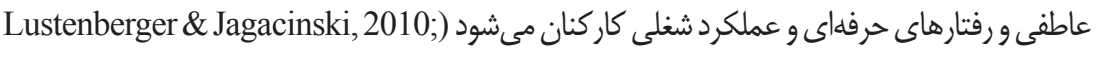
Leung et al., 2011; Perlow \& Repenning, 2009; Zhao et al., 2013; (Hitlan \& Noel, 2009;

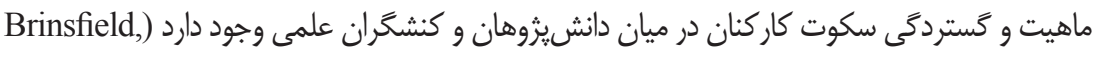

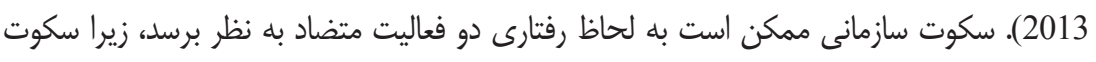

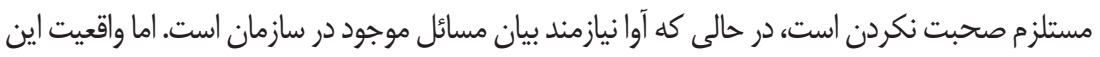

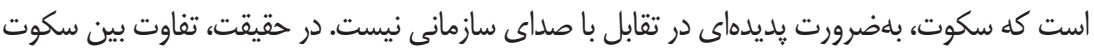

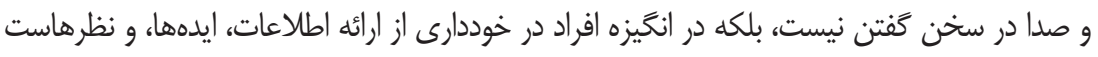

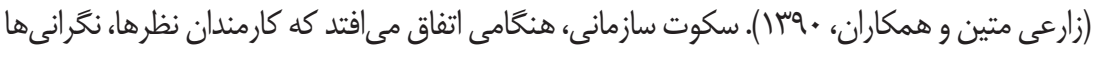
يا ايدههاى سازنده خود را درباره مسائل مربوط به كار يا سازمان بيان نكنند (Dyne et al., 2003).

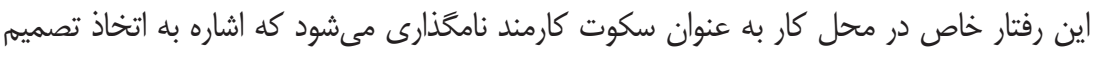

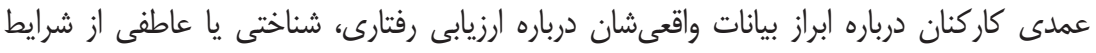

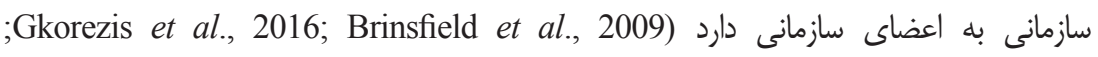
Kish-Gephart et al., 2009; Pinder \& Harlos, 2001 سازمانى را بيان نكردن صادقانه عقايد كاركنان درباره عملكرد و وضعيت سازمان تعريف مى كنند. در 
مفهوميردازى ديخر اين گونه تشريح مىشود كه برخى از كار كنان با نظر جمع موافقت مى كنند وخودشان را با نظرهاى آنها تطبيق مىدهند، به اين ترتيب، ارتباطات مبرمه مىشود. كار كنان دانش و افكار خود

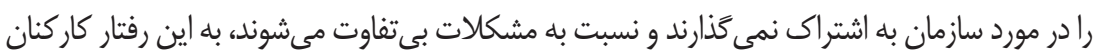
سكوت سازمانى مى گويند (امين بيدختى و عليجانى، هوسا). در واقع سكوت سازمانى، فرايندى سازمانى

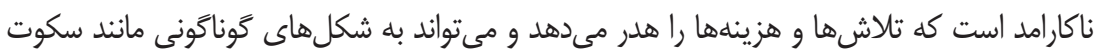

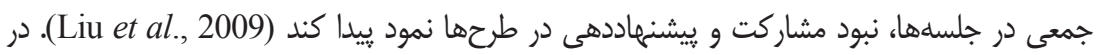

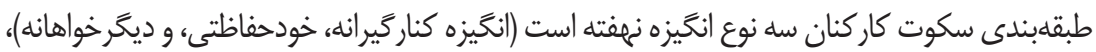

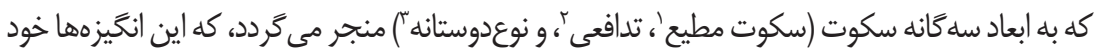

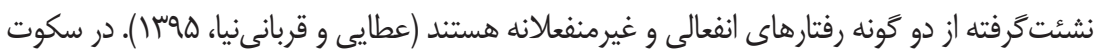

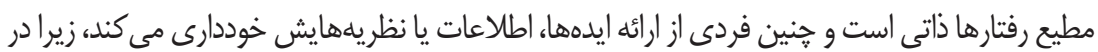
برابر هر شرايطى تسليهم است. افرادى كه رفتارهايى خون كممشار كتى، اهمال كارى، مسامحه، و غفلت

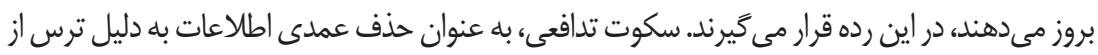

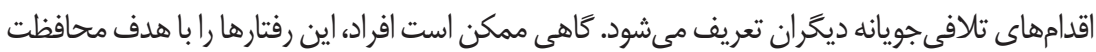

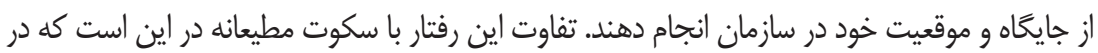

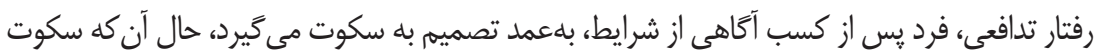

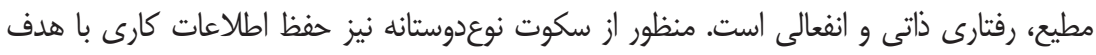

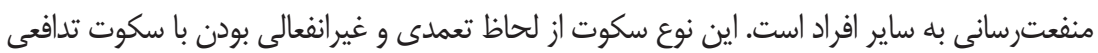
شباهت دارد، اما از اين منظر كه بيشتر در بى منفعت جمعى بلجايى منفعت شخصى است، با سكوت

تدافعى متفاوت است (Perkins, 2014). بررسى ادبيات يزوهش نشان مىدهد كه سكوت كاركنان دو بُعد ديخر را نيز در بر مى كَيرد. بُعد

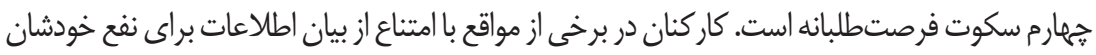

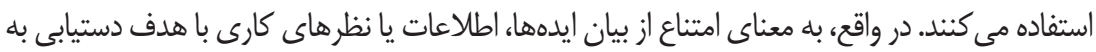

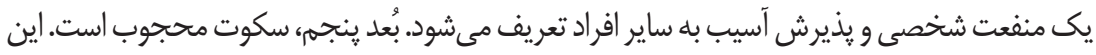
نوع سكوت به معنى ترديد داشتن در عمل و صحبت كردن به دليل فقدان اعتماد به نفس است و ممكن است قدرى باسكوت تدافعى همبوشانى داشته باشد، زيرا اين بُعد براى جلو تيرى از ييامدهاى منفى ارتباط

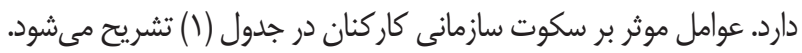

1. Passive Silence

2. Defensive

3. Prosocial 


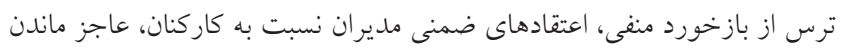

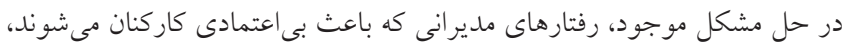

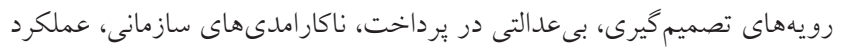

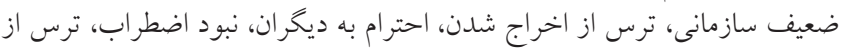

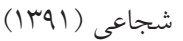

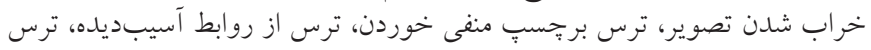

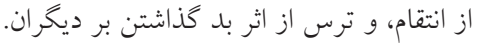

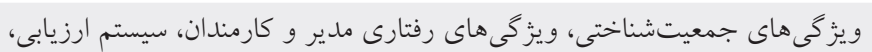

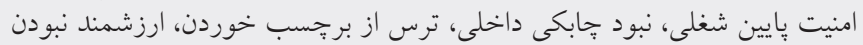

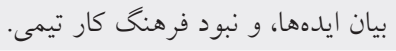

رستخار و روزبان (1rar)

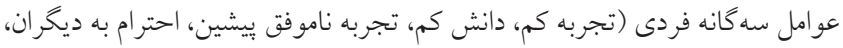

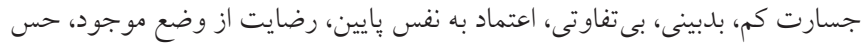

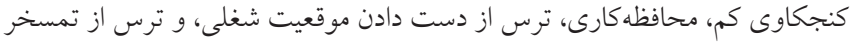

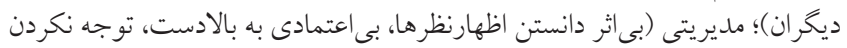

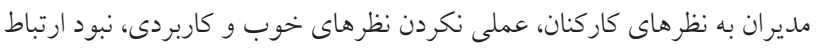

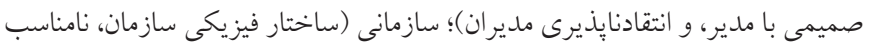

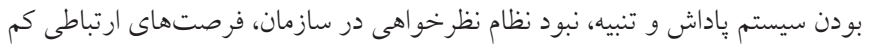

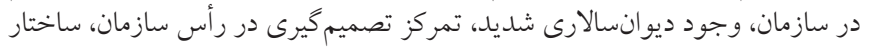

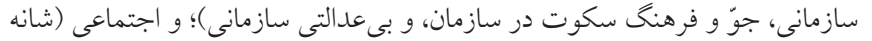

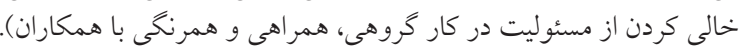

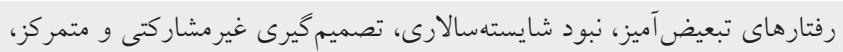

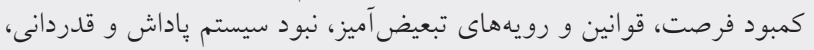

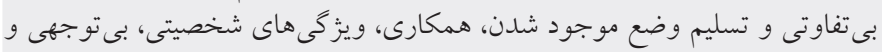
حمايت نكردن مدير ان، و نبود امنيت شغلى هورئ.

(IrqY)

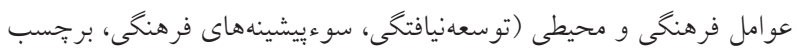

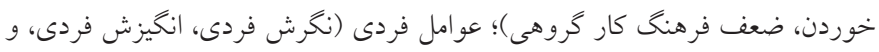

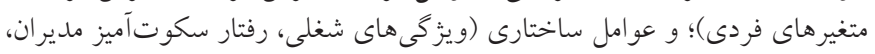

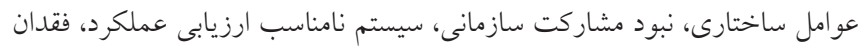

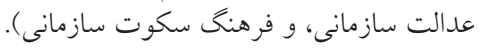

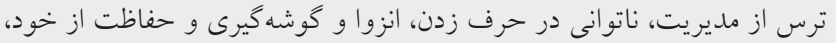

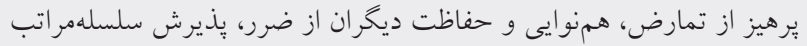

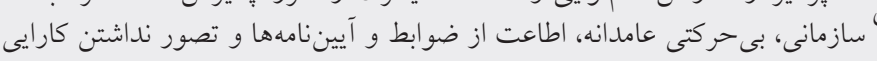

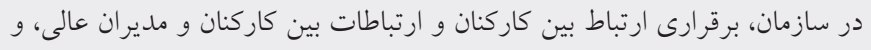

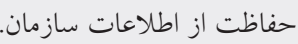


بنابراين، سازمانهاى كارامد اغلب نظرها، يشنهادها، و نغرانى هاى كار كنان خود را تشويق و مد نظر قرار مىدهند، زيرا صداى كاركنان براى اثربخشى عملكرد سازمانى حياتى است (Fast et al., 2014).

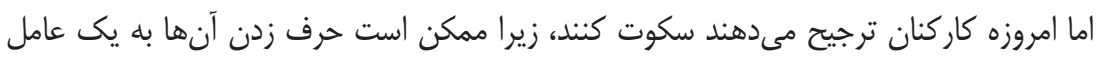

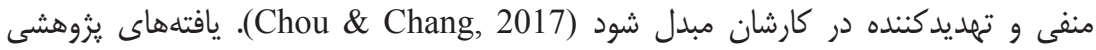
بيانكر اين نكته است كه سكوت كار كنان مىتواند اثرهاى منفى بر عملكرد موثر در تصميمَّيرى،

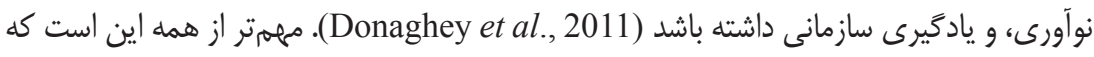

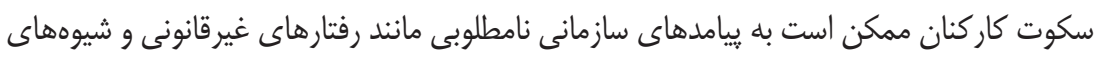
غيراخلاقى منجر شود (Knoll \& Van Dick, 2013, Premeaux, 2009).

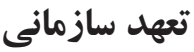

تعهد سازمانى نكَرشى است كه در آن كاركنان هويت خود را با سازمان تعيين مى كنند. وقتى

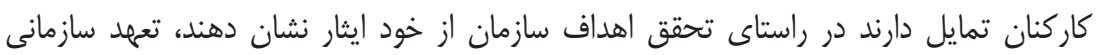

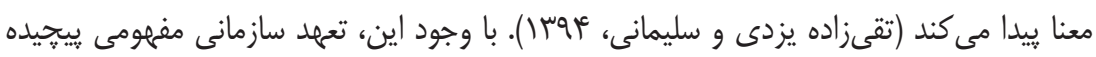

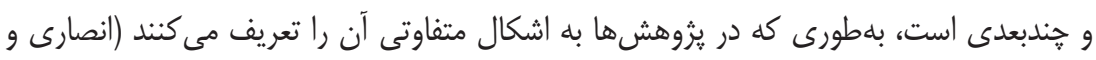

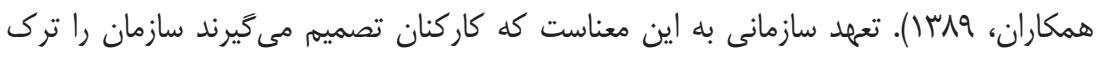

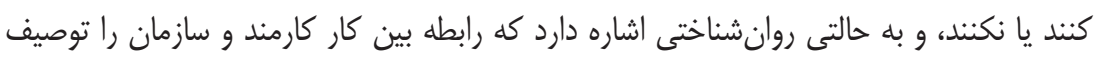

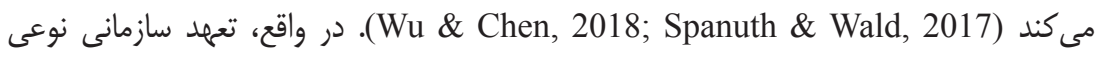
واكنش نيروى انسانى به تمام عناصر و عوامل سازمان است (Gunlu et al., 2010). در تعريف (W.

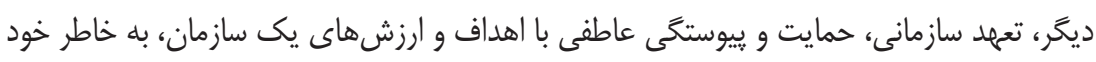

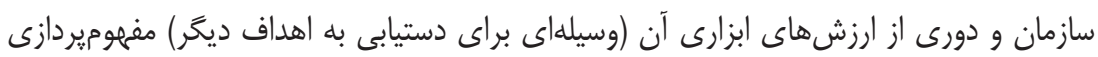

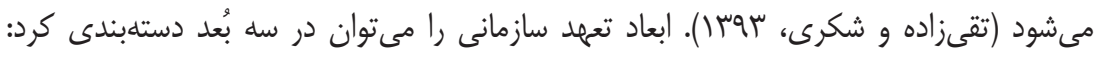

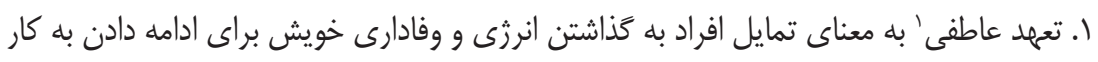

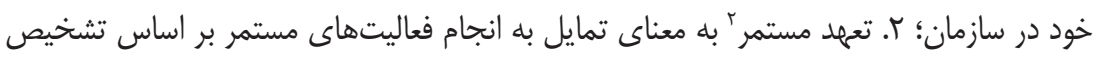

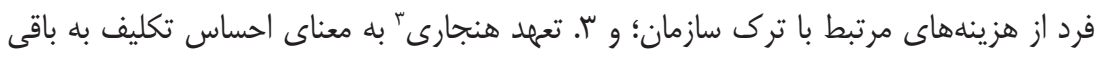

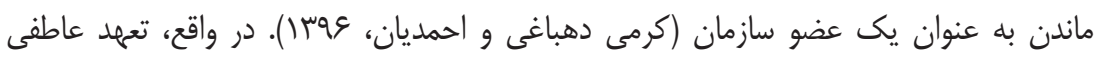

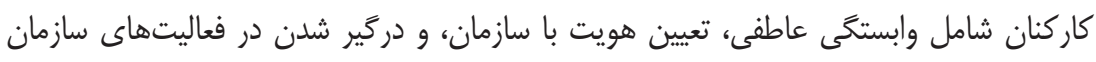

1. Emotional

2. Continuous

3. Normative 
است. تعهد هنجارى به عنوان نوعى تعهد و التزام تعريف مىشود كه كاركنان را به سمت اين

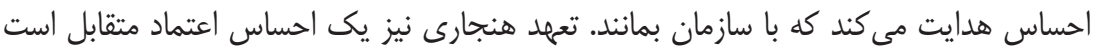

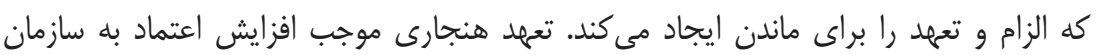

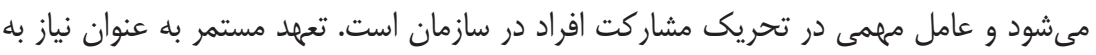

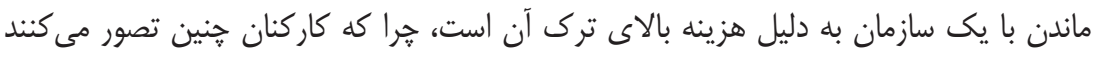

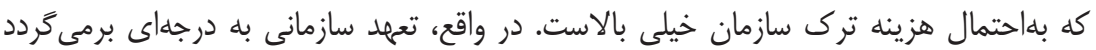
كه يك شخص ارزشها، اهداف، حس وظيفهشناسى، و وفادارى به سازمان خود را درونى ميى كند

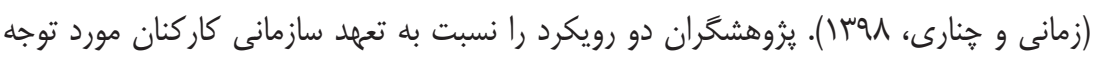

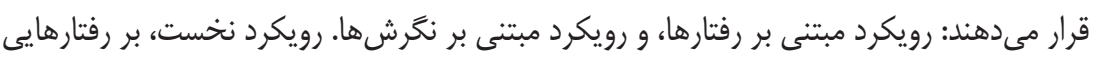

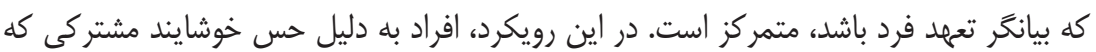

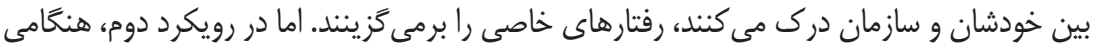

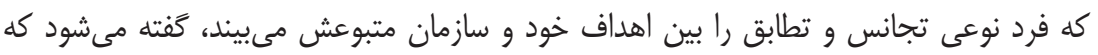
تعهد در نكرش او وجود دارد. در خنين شرايطى، او هويت خود را در هويت سازمان متبلور مىبيند

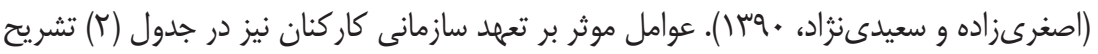

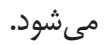


جدول ب: عوامل موثر بر تعهد سازمانى كار كنان

\begin{tabular}{|c|c|}
\hline عوامل موثر بر تعهد سازمانى كاركنان & \\
\hline 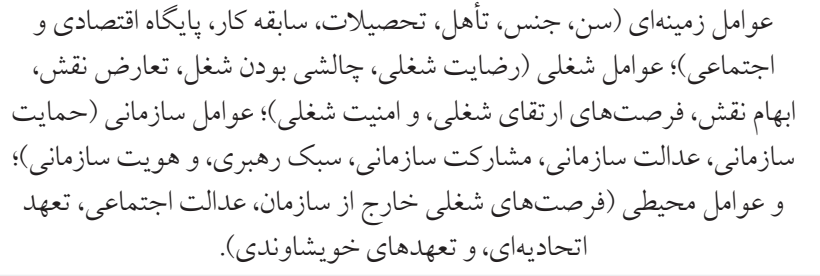 & 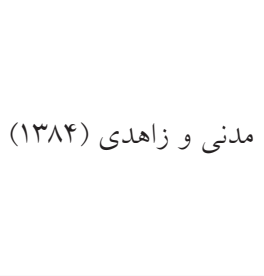 \\
\hline 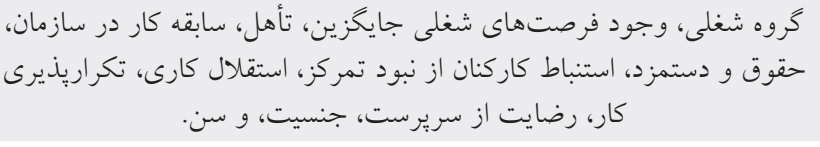 & 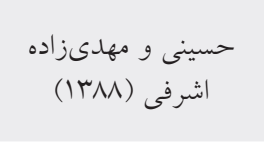 \\
\hline نخرش اعضا نسبت به مديران ارشد، ويزگى هاى شغل، عدالت در يرداختها: & 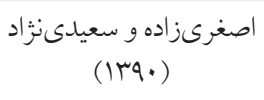 \\
\hline 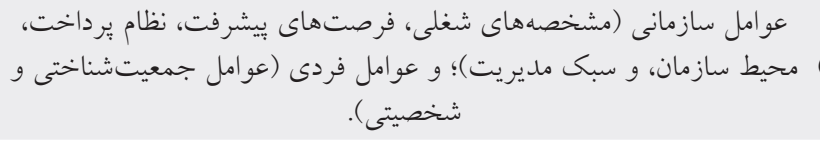 & \\
\hline 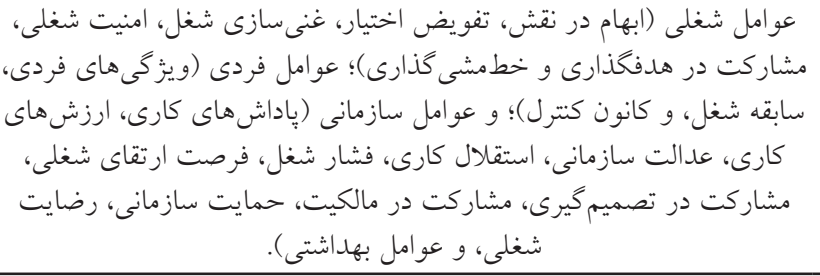 & 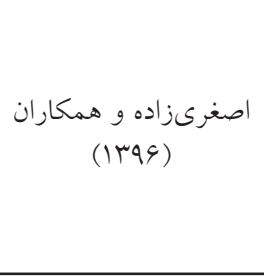 \\
\hline
\end{tabular}

مسئوليت بذيرى اجتماعى

مسئوليت اجتماعى در سازمان از عوامل اساسى بقاى هر سازمان محسوب مىشود.

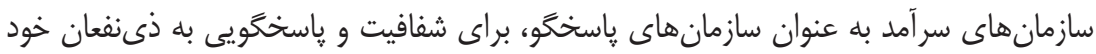

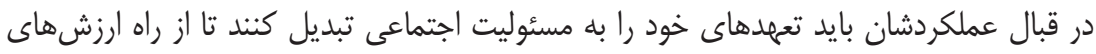

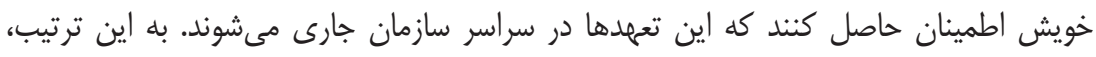

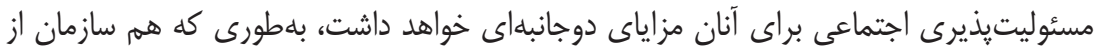

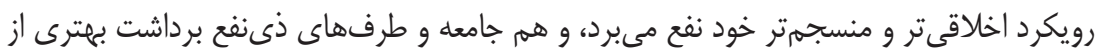

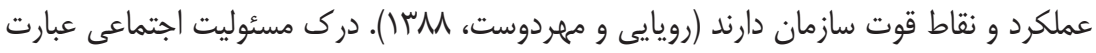

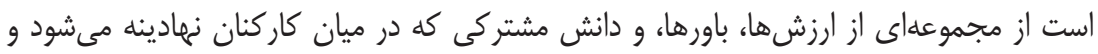


در انجام فعاليتهاى سازمانى به توليد و ارزشافزوده منجر مىشود، و درك كامل آن در سازمان

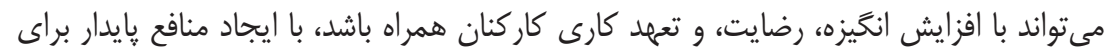

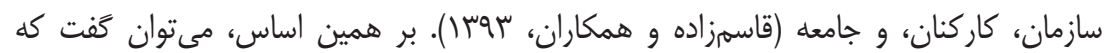
مسئوليتيذيرى اجتماعى از جمله مهمترين عناصر فسلفه وجودى سازمانهاست. به نحوى كه

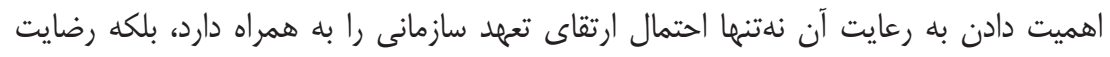

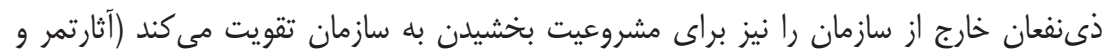

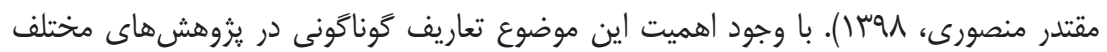

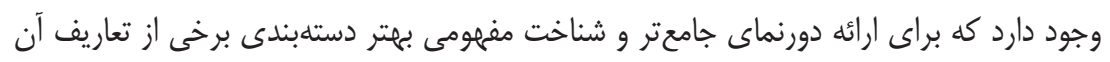

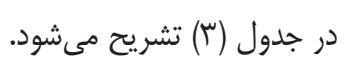

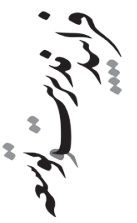

جدول ऍّ: تعاريف و مفهوميردازىهاى مسئوليت اجتماعى كار كنان

\begin{tabular}{|c|c|}
\hline تعاريف و مفهوميردازىها & يُزوهشخر ان (سال) \\
\hline 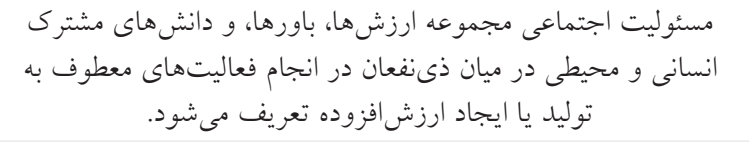 & حقيقتيان و همكاران (1) ح||) \\
\hline 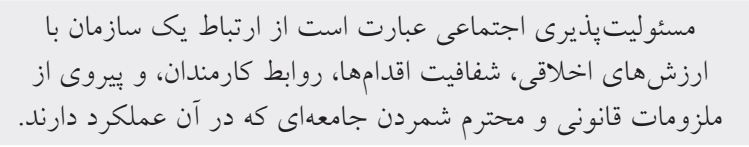 & مهدى (س (Ir) \\
\hline 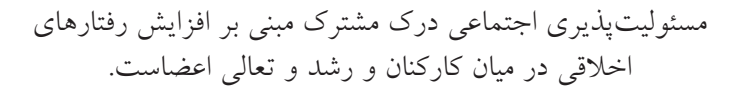 & اردلان و همكاران (rquq) \\
\hline 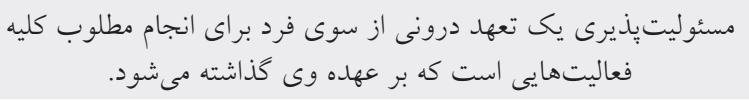 & زارع و همكاران (ه (1) \\
\hline 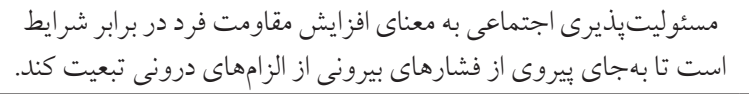 & 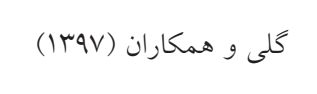 \\
\hline
\end{tabular}

كارول'(1991)، ابعاد مسئوليتيذيرى اجتماعى را در جههار بُعد مطرح مى كند كه عبارتاند

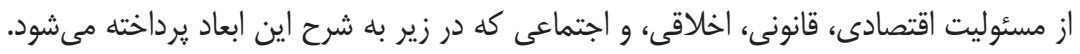

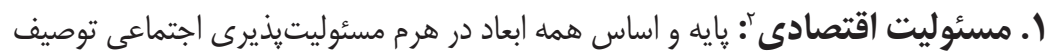
مىشود، زيرا همه مسئوليتهاى كسبو كارهاى ديخر بر ييشينى هائهاى مسئوليت اقتصادى نهاده

1. Carroll

2. Economical Responsibility 
مىشود. از لحاظ تاريخى نيز سازمان هاى تجارى به عنوان نهادهاى اقتصادى طراحى و براى ارائه كالا و خدمات به اعضاى جامعه ايجاد مى شئوند.

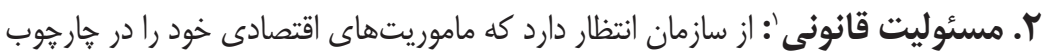
قانون ييخيرى كند. مسئوليت قانونى به عنوان لايه دوم هرم مسئوليتيذيرى اجتماعى مطرح است.

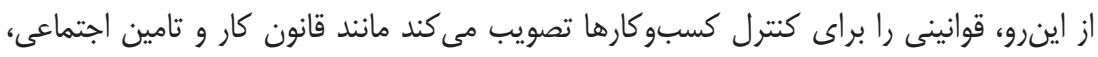
قانون ايمنى و سلامت كار، قانون ضدفساد اقتصادى يا حفظ محيطزيست در زمره اين قوانين كاين ماندين

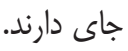

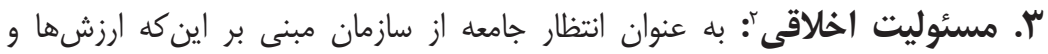

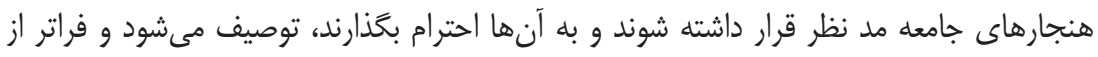

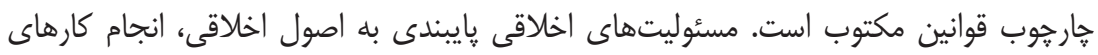
درست، عدالت، انصاف، و احترام به حقوق مردم را در بر مى ئيرد.

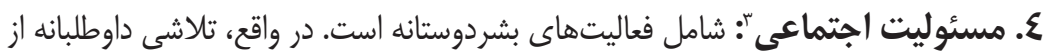

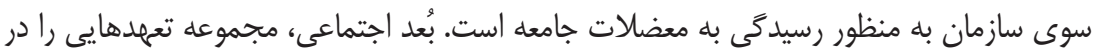

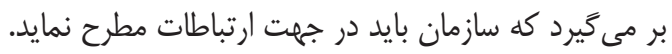

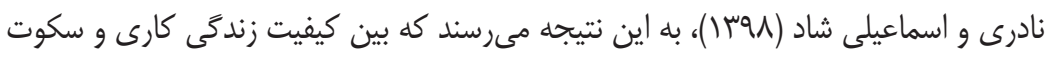

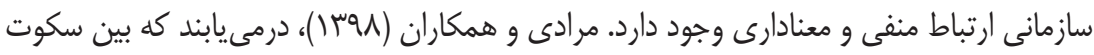

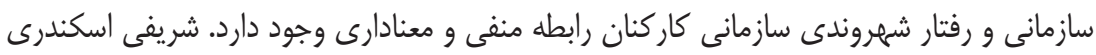

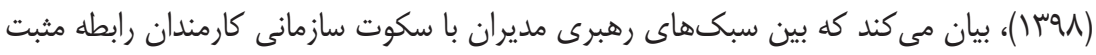

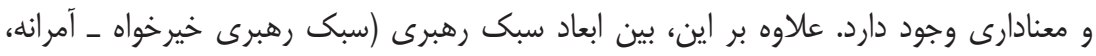

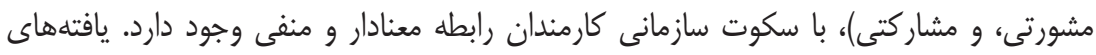

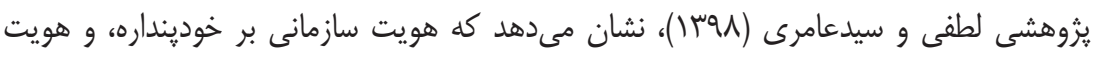
سازمانى بر سكوت سازمانى اثر مثبت و معنادارى دارد، علاوه بر اين، خوينداره نيز سكوت سازمانى

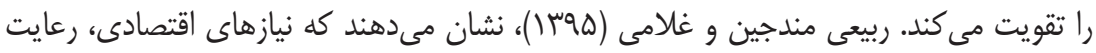

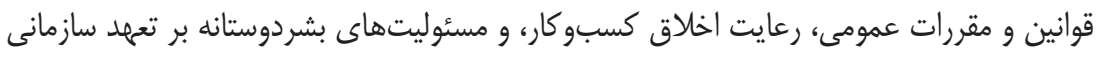

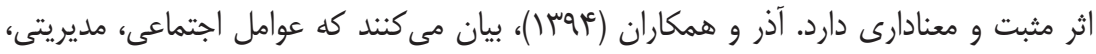

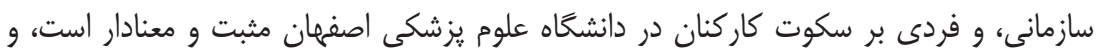

1. Legal

2. Moral

3. Social 
همجنين رفتار و جوّ سكوت در سازمان تاثير منفى بر تعهلد كاركنان و مولفههاى آن دارد.

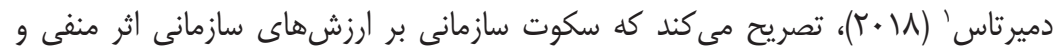
معنادارى دارد. همجنين سكوت سازمانى بر تعهلد عاطفى كاركنان نيز اثر منفى و معنادارى دارد.

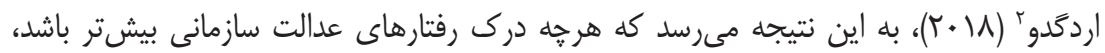
بديينى سازمانى كمتر مىشود. علاوه بر اين، بين سكوت سازمانى و بدبينى سازمانى همبستخى

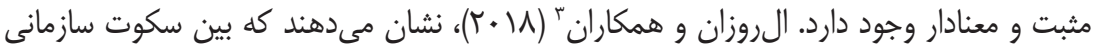

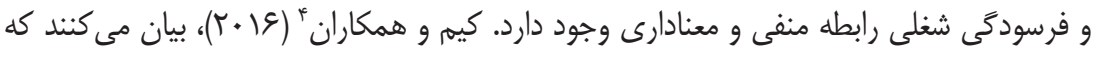
ابعاد جههار كانه مسئوليتيذيرى اجتماعى (قانونى، خيرخواهانه، اقتصادى، و اخلاقى)، ضمن توجه به فعاليتهاى بازاريابى سازمان از طريق تعهد شغلى كاركنان به كاهش ترك شغل و سازمانى منجر

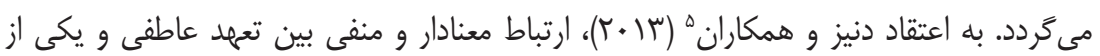

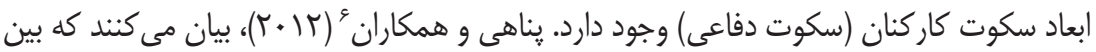
فرصتهاى ارتباطى و تعهد سازمانى كاركنان با رفتار سكوت كار كنان همبستخى منفى وجود دارد.

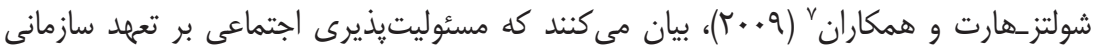
اثر معنادار و مثبتى دارد. شواهد و ييشينه تجربى داخلى و خارجى بازگً كننده اين نكته است كه سكوت سازمانى بر كارايى و اثربخشى سازمانى اثر منفى دارد و باعث فرسايش سرمايه انسانى سازمانها، و در سطح كلان مانع رشد و توسعه اقتصادى كشورها مىشود. سكوت به معناى خوددارى كاركنان از بيان ديدكامها، انتقادها، و نظرهاى شخصى در مورد مشكلات سازمان دانشگاه است. به نوعى رفتار

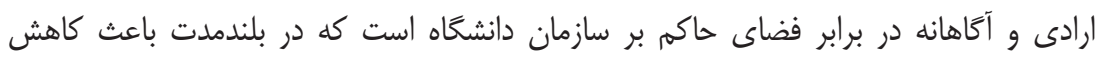

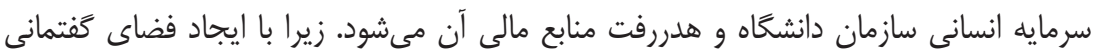
منفى عليه ابراز ايدههاى جديد و دريافت بازخوردهاى انتقادى و منفى، مانع آفرينش تغيير و توسعه سازمان دانشگاه مىشود. در حالى كه همكنشى و مشاركت كاركنان در امور سازمان دانشگاه براى توانمندسازى كاركنان و بهبود عملكرد دانشگاه بيش از ييش ضرورى است. در اين يزوهش، به

1. Demirtas

2. Erdogdu

3. Al-Rousan et al.

4. Kim et al.

5. Deniz et al.

6. Panahi et al.

7. Schulz-Hardt et al. 
تبيين روابط بين سكوت سازمانى و تعهد سازمانى بر مسئوليتيذيرى اجتماعى كاركنان يرداخته

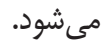

فرضيه يكم: سكوت سازمانى اثر منفى و معنادارى بر مسئوليتيذيرى اجتماعى دارد. فرضيه دوم: سكوت سازمانى اثر منفى و معنادارى با تعهد سازمانى دارد.

فرضيه سوم: مسئوليتيذيرى اجتماعى اثر مثبت و معنادارى بر تعهد سازمانى دارد.

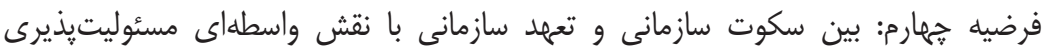

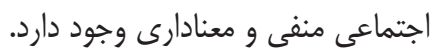

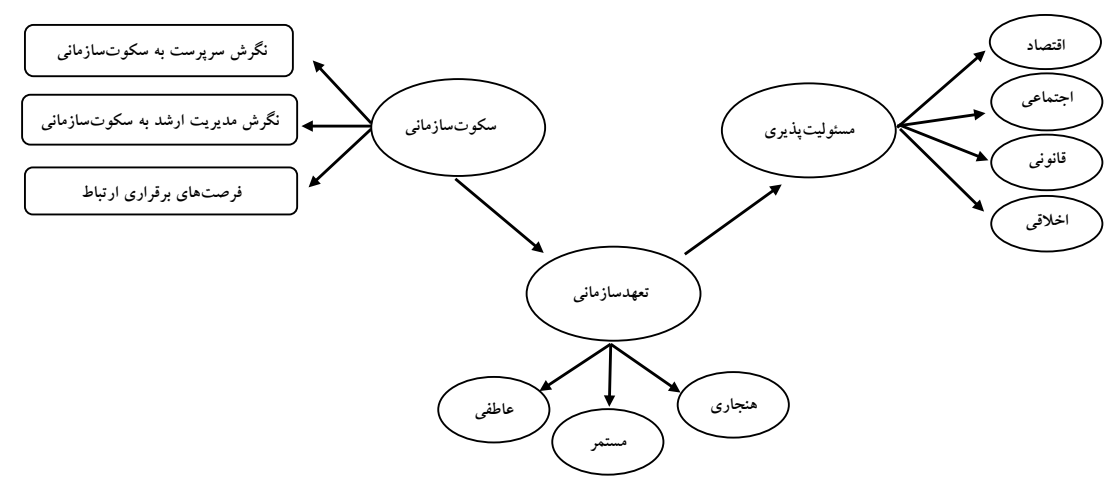
شكل 1: مدل مفهومى بزؤهش

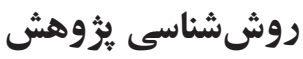
يزوهش حاضر از نظر هدف، كاربردى و از لحاظ كَردآورى دادهها از نوع همبستخى است.

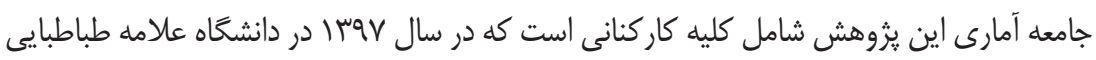

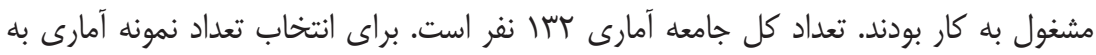

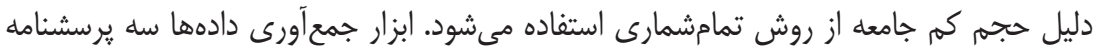

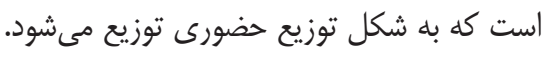

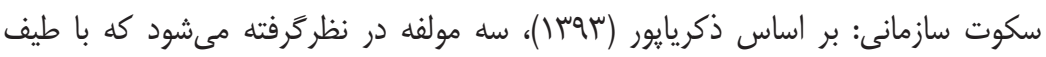

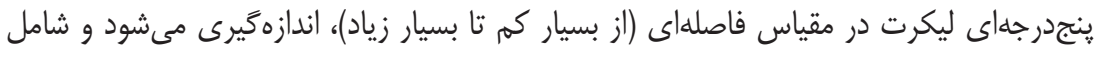


نخرش مديران ارشد به سكوت، نخحرش سريرستان به سكوت، و فرصتهاى برقرارى ارتباطات

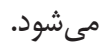

تعهد سازمانى: بر اساس آلن و ماير' (•199)، داراى مقياس درجهبندى (از بسيار مخالفم تا بسيار موافقم) است كه در سه بُعد عاطفى، هنجارى، و مستمر سنجشيذير است.

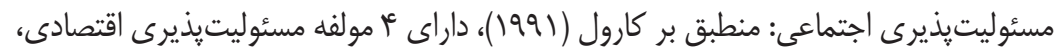

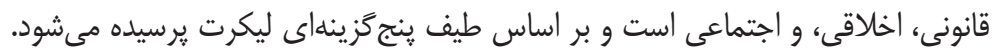

جدول †: يافتهاى توصيفى متغير هاى بزوهش

\begin{tabular}{|c|c|c|}
\hline انحراف معيار & ميانگين & شاخص آمارى مقياس \\
\hline $9 / 00$ & $\mid+1 / 0 \wedge$ & سكوت سازمانى \\
\hline$\Lambda / \notin V$ & $V \cdot / \Lambda \cdot$ & مسئوليت تذيرى اجتماعى \\
\hline $1 T / \wedge 9$ & $1 \cdot r / 91$ & تعهد سازمانى \\
\hline
\end{tabular}

نظر به اين كه اساس مدلسازى معادلهاى ساختارى بر مبناى ماتريس واريانس-كوواريانس

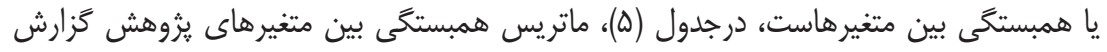

\begin{tabular}{|c|c|c|c|}
\hline \multicolumn{4}{|c|}{ جدول ه. ماتريس همبستخى متغير هاى يزووهش } \\
\hline تعهد سازمانى & مسئوليتيذيرى اجتماعى & سكوت سازمانى & \\
\hline & & 1 & سكوت سازمانى \\
\hline & 1 & $\cdot / \pi q^{*}$ & مسئوليت يذيرى اجتماعى \\
\hline 1 & $\cdot / 0 \Lambda^{\prime \prime}$ & $\cdot / T V^{*}$ & تعهد سازمانى \\
\hline
\end{tabular}


نتايج جدول (ه) نشان مىدهد كه رابطه بين سكوت سازمانى با مسئوليتيذيرى اجتماعى و

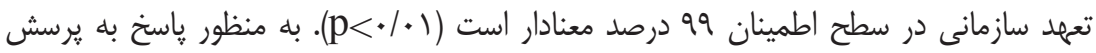

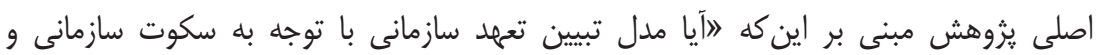

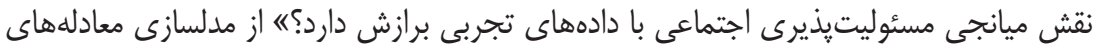

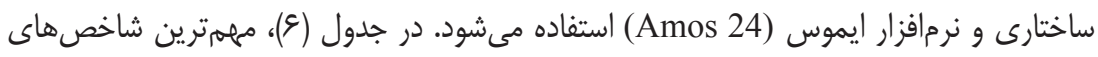

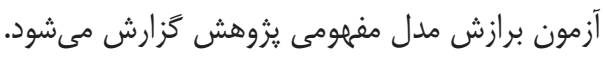

جدول 9: شاخصهاى برازش مدل

\begin{tabular}{|c|c|c|c|c|c|c|c|}
\hline AGFI & GFI & CFI & NNFI & NFI & RMSEA & df $/ 2 \chi$ & شاخصهاى برازش \\
\hline$\cdot / 90$ & .199 &.$/ 99$ & . $/ 9 \mathrm{Y}$ & $\cdot / 90$ & .1 .4 & $1 / T 1$ & مقدار بهدستآمده \\
\hline
\end{tabular}

با توجه به اين كه هر يك از شاخصهاى بهدستآمده برازش مدل بلهتههايى دليل برازندكى

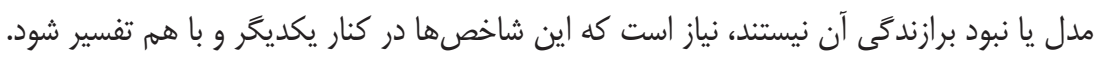

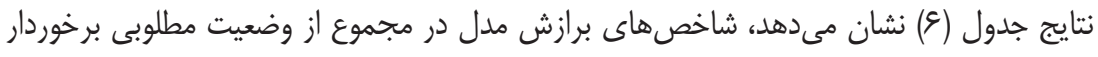

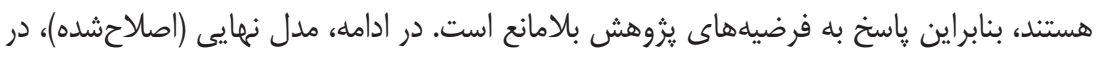

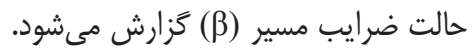

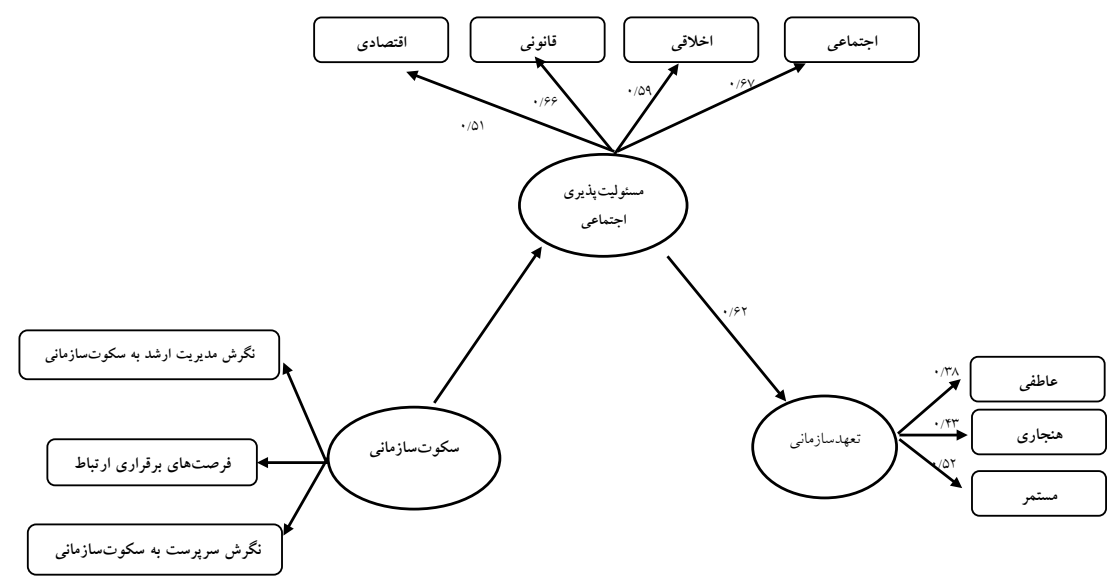

شكل r: ضرايب استانداردشده مسيرهاى مدل نهايع تبيين تعهد سازمانى 
جدول Y. ضرايب و معنادارى اثرهاى مستقيم

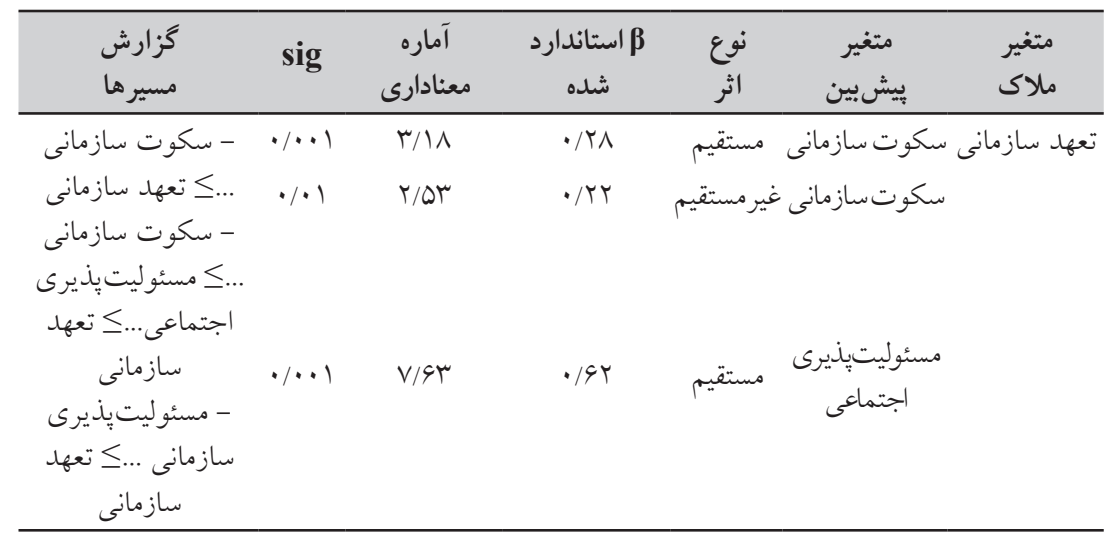

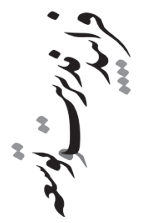

آزمون ضرايب مسير شكل (T) نشان مىدهد كه ضريب استانداردشده مسير مستقيه سكوت

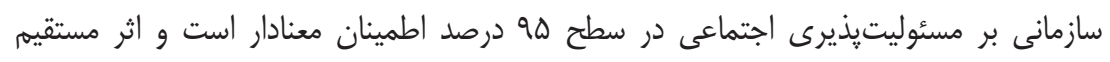

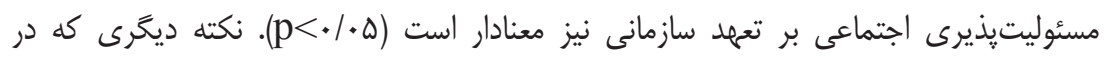
اين نمايه بايد مورد توجه قرار گيرد، مثبت بودن ضرايب مسير مربوط به متغير ملاكى (تعهلد

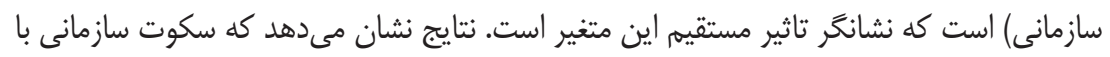

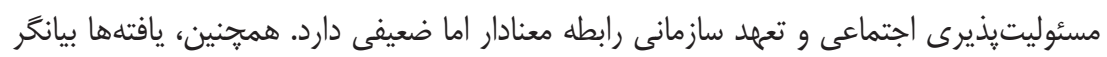
آن است كه همبستخى مثبت بسيار بالايى بين تعهلد سازمانى و مسئوليتيذيرى اجتماعى وجود

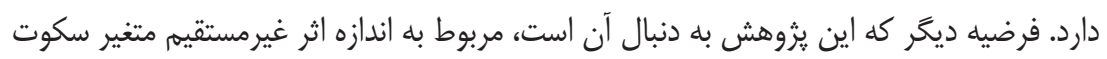
سازمانى بر تعهلد سازمانى از طريق مسئوليتيذيرى اجتماعى است. نتايج آزمون اثرهاى غير مستقيهم

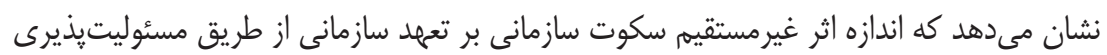

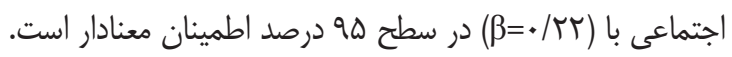

\section{بحث و نتيجه كيرى}

هدف از يثوهش حاضر، تبيين روابط بين سكوت سازمانى و تعهد سازمانى بر مسئوليتيذيرى

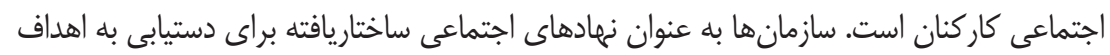
خاص توصيف مىشوند، بنابراين بايد بتوانند دارايىهاى خود را در جهانى رقابتى و جهانى شده حفظ إنظ كنند (Gencer et al., 2018). بنابراين، بايد بسترى را براى ييدايش جنين شرايطى فراهم سازند.

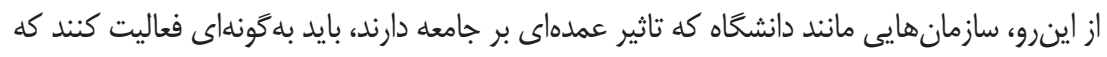


اثرهاى مثبت حاصل از فعاليت خود را به بيشينه و اثرهاى منفى را به كمينه برسانند. همجنين، به عنوان

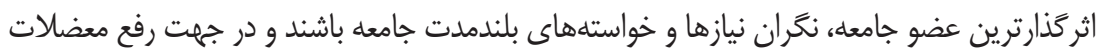

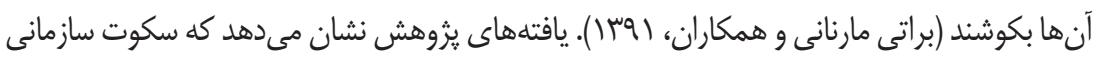
بر مسئوليتيذيرى اجتماعى كاركنان اثر منفى و معنادارى دارد. همجنين، مسئوليتيذيرى اجتماعى إنى

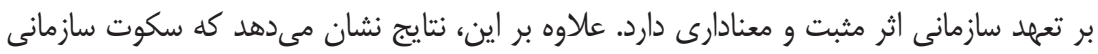

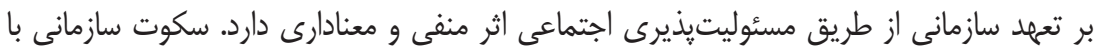

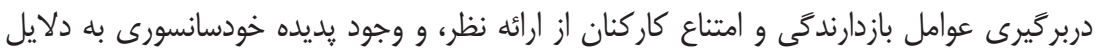
كَوناكون (سكوت مطيع، تدافعى، نوعدوستانه، فرصتطلبانه، و محجوب)، بر ميزان مسئوليتيذيرى

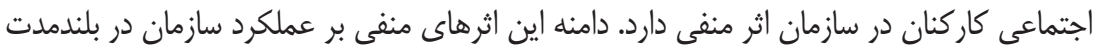

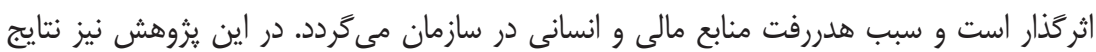
بيانكر اين نكته است كه سكوت سازمانى (با مولفهاى فرصتهاى برقرارى ارتباط، نكرش مديريت

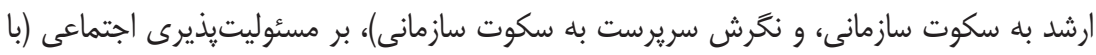

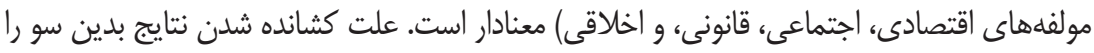

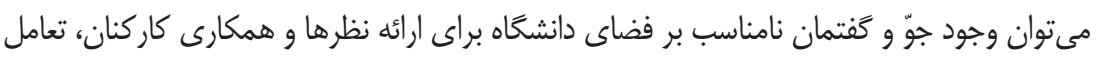

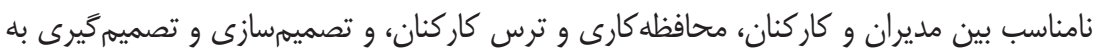
شكل متمركز در محيط كارى دانشكاه قلمداد كرد.

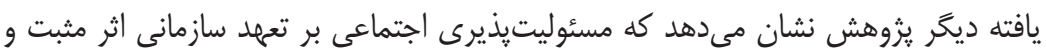

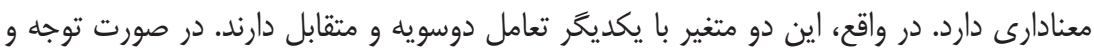

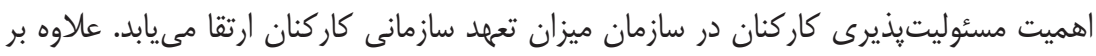

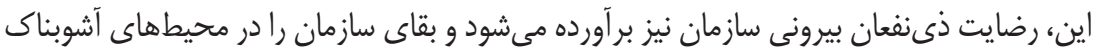

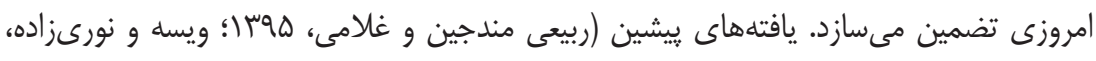

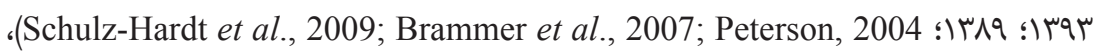
نشان مىدهد كه بين اين دو متغير ارتباط مثبت و معنادارى وجود دارد. در واقع، جنين مىتوان تبيين

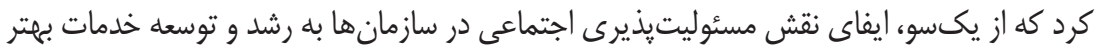
به مشتريان، تشويق كار كنان به همكارى بيشتر و بهتر در سازمان، و گسترش سطح رضايتمندى

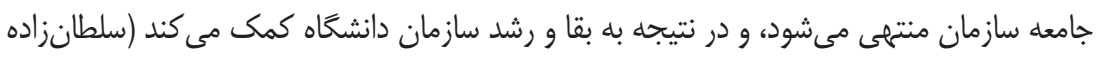

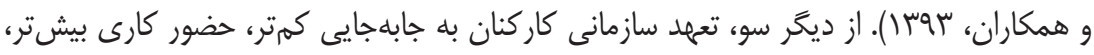
عملكرد درون نقشى و برون نقشى بالاتر، خدمتر سانى بهتر، و رضايت شغلى كار كنان منجر مى شودا. 
جهت

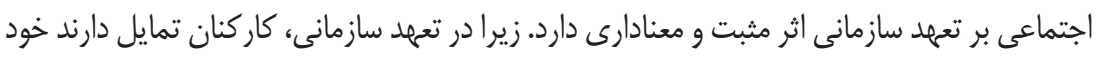

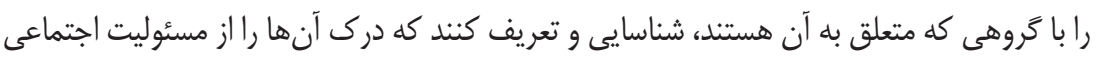

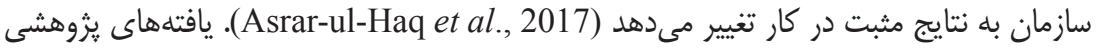

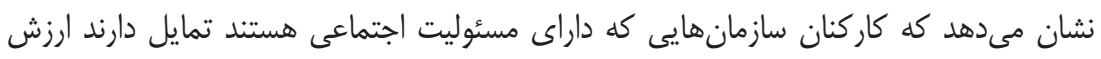

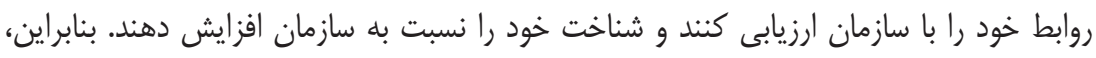

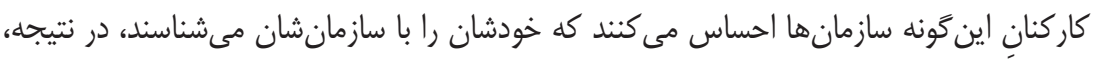
تعهد و وفادارىشان نسبت به سازمان ارتقا مىيابد (Cullen et al., 2003; Schwepker, 2001)

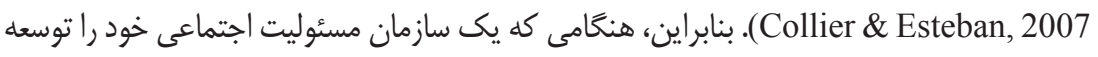

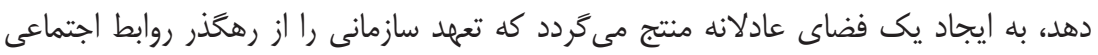
ارتقا مىبخشد (Gong et al., 2010). در اين صورت، كاركنان متعهد در سازمان مى كوشند كه آنهان

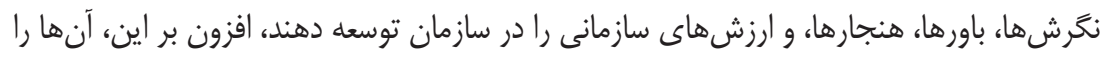
در جهت انجام مسئوليت اجتماعى فردى و سازمانى در جامعه تسرى مىدهند. اين فراگرد علاوها

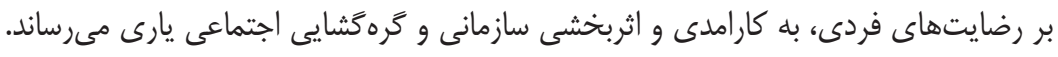

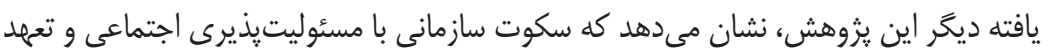

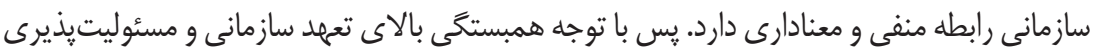

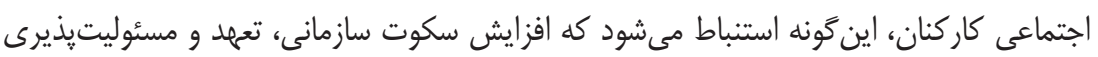
اجتماعى كاركنان را كاهش مىدهد. به عبارتى ديخر، سكوت سازمانى از جمله عوامل اساسى إسى

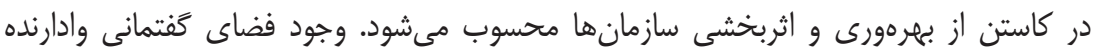

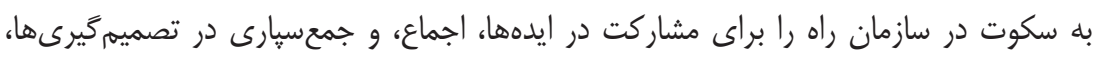

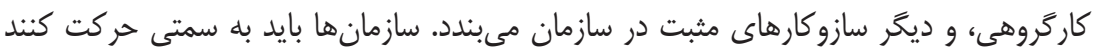

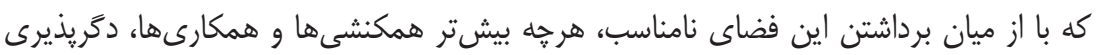

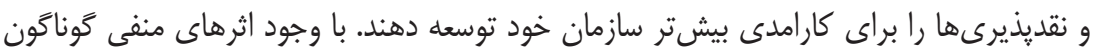

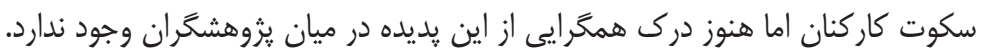
يافته ديخر اين بزوهش مربوط به سنجش اثر غيرمستقيم سكوت سازمانى بر تعهد سازمانى از

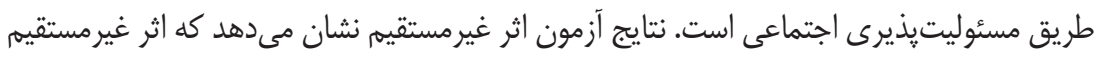

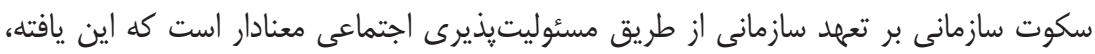

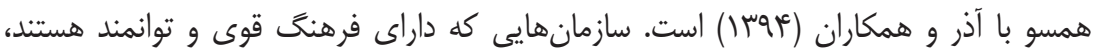


كاركنان آنها نسبت به ارزشها و اهداف سازمانى احساس تعهد و مسئوليت مى كنند. تعهد سازمانى از برداشت كاركنان از عدالت رويهاى و عدالت توزيعى درون سازمان متاثر است. هنكامى إنى

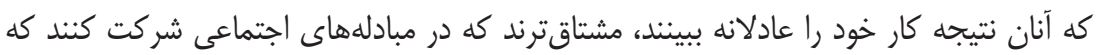

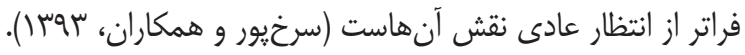

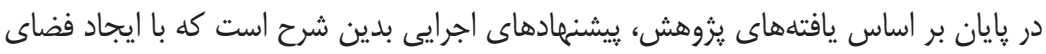

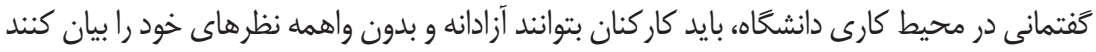

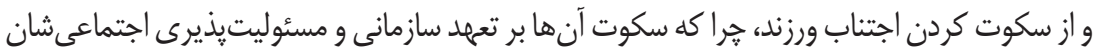
اثر منفى دارد. به مديران دانشخاه ييشنهاد مىشود كه در تصميمسازى و تصميمگيرى ها، كاركنان را در تعريف نقشهاى كارى مشاركت دهند تا كيفيت روابط و اعتماد بين فردى افزايش يابد. ضمن اين كه مديران بايد بازخوردهاى متناسب با عملكرد نشان دهند تا كاركنان با مشاهده نتايج نظرهاو كارشان احساس اثر كَارى داشته باشند. به مديران دانشخاه ييشنهاد مى شود كه با بكار كَيرى رهبرى

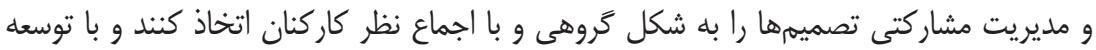

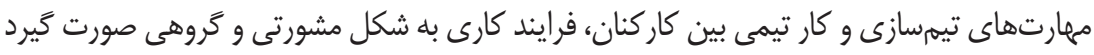

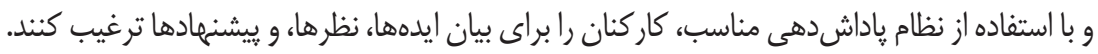

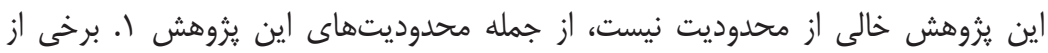

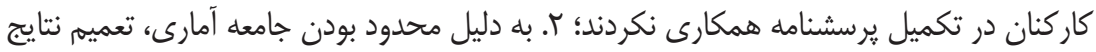

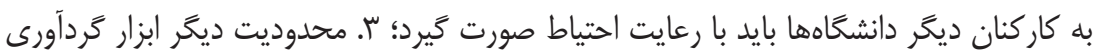
اطلاعات است كه فقط از يرسشنامه استفاده شده است و از روشهاى ديخر از جمله مصاحبه

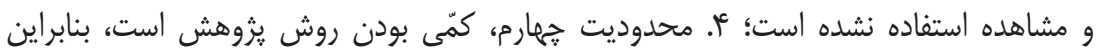
نمىتوان بهطور دقيق ابعاد كوناكون را شناسايى و تحليل كرد؛ و ه. استفاده از يرسشنامههاى ترجمهشده و مرتبط با زيستبوم ديخر كشورها و فرهنگ بهاى سازمانى آنها. براى يزوهش هاى بعدى ييشنهاد مىشود كه از روش هاى ديخر كيفى يا آميخته براى تحليل دقيقتر متغيرها انجام شود. ييشنهاد مىشود در صورت استفاده از روش كمّى براى تحليل لايههاى ينهان و براي

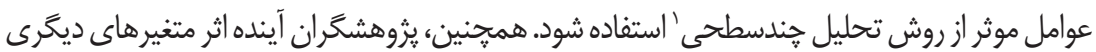

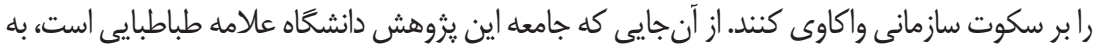
يروهشخران ييشنهاد مى شود تاثير اين سه متغير رادر ديخر دانشخاهها مورد مطالعه قرار دهند. 


\section{منابع}

\section{الف) فارسى}

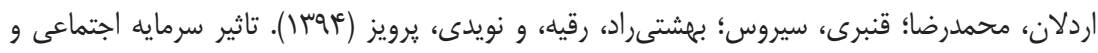

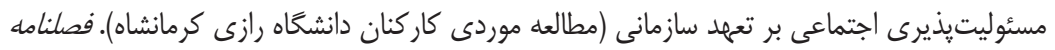

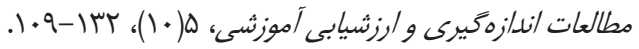

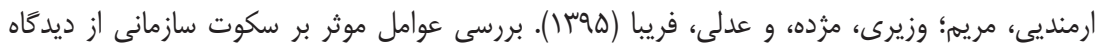

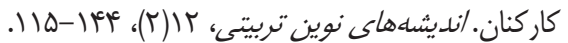

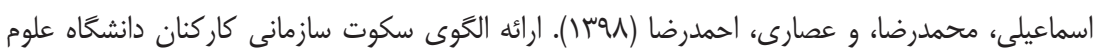

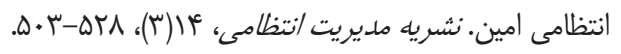

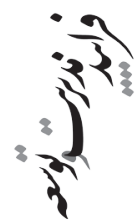

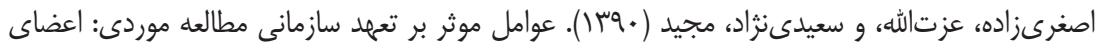

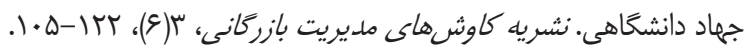

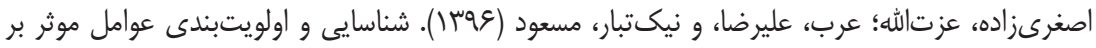

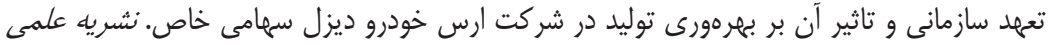

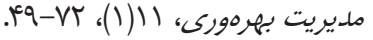

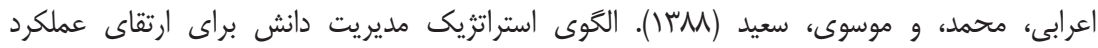

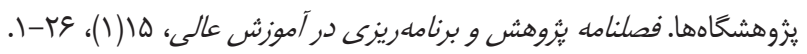

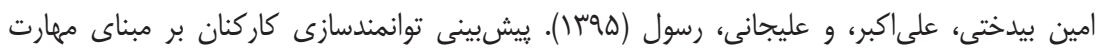

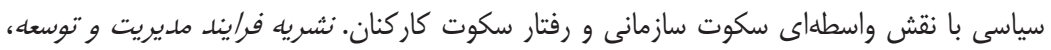

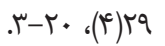

اناركى اردكانى، داود؛ حسنيور، اكبر؛ عبداللمى، بيثن، و عباسيان، حسين (Vوس I). سازهيردازى استعداد در

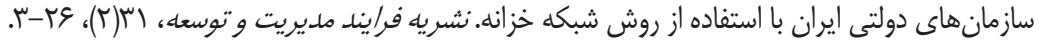

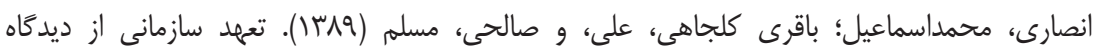

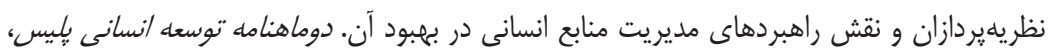

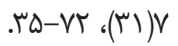
آثارتمر، محمد، و مقتدر منصورى، البرز (1وس (). بررسى نقش مولفههاى مسئوليت اجتماعى بر سلامت سازمانى

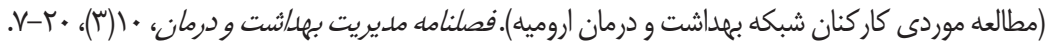

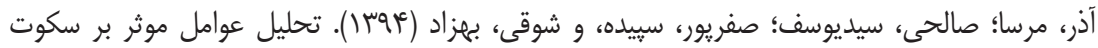

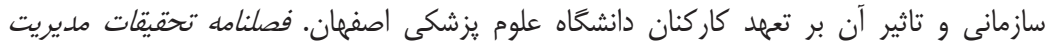

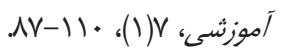

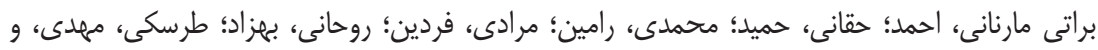

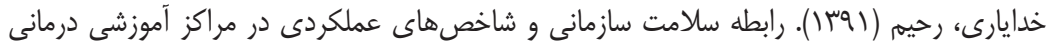




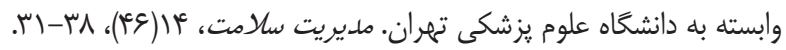

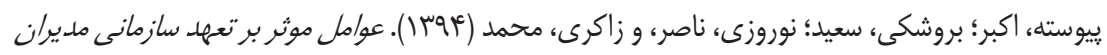

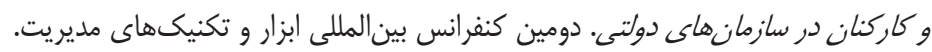

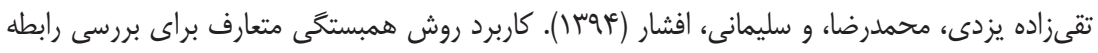

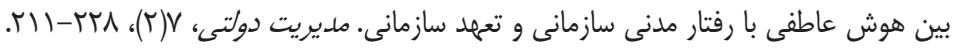

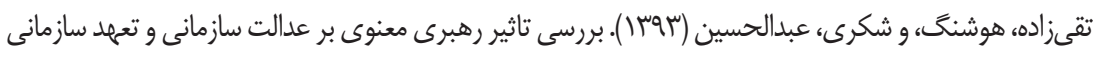

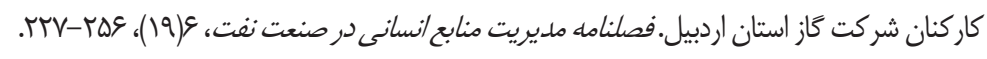

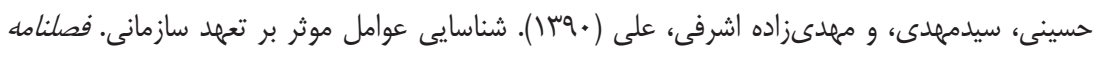

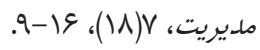

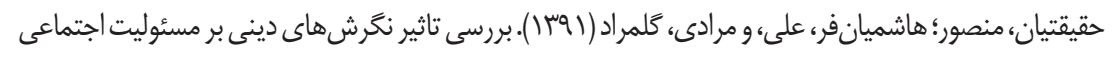

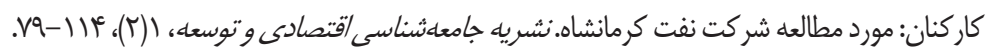

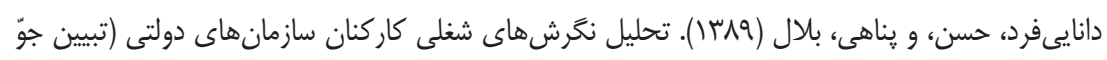

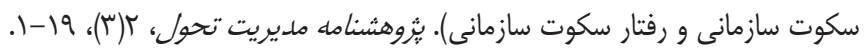

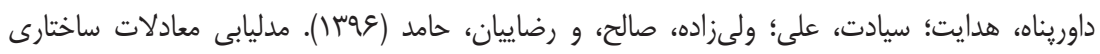

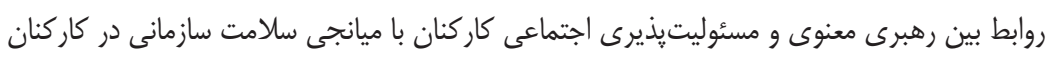

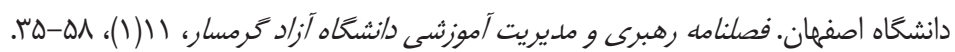

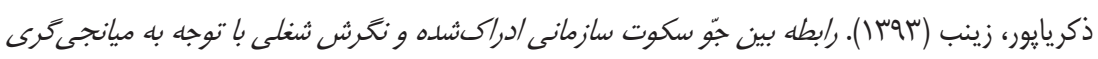

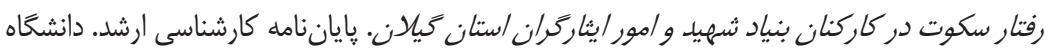

$$
\text { آزاد اسلامى رشت. }
$$

ربيعى مندجين، محمدرضا، و غلامى، مهديه (هوس (). بررسى تاثير مسئوليت اجتماعى بر تعهد سازمانى

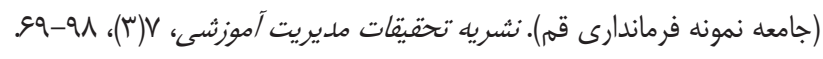

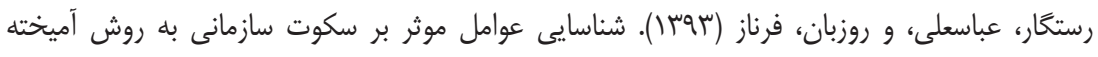

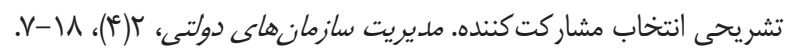

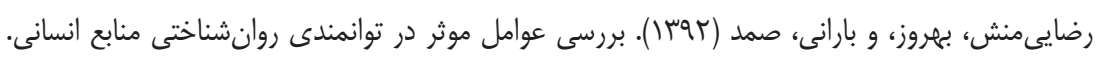

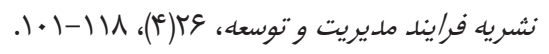

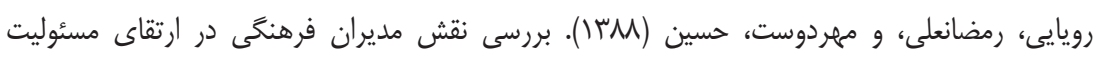

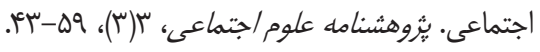

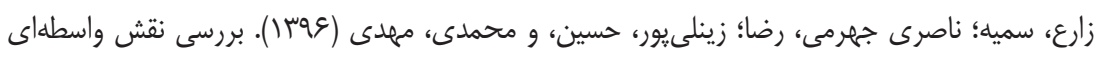

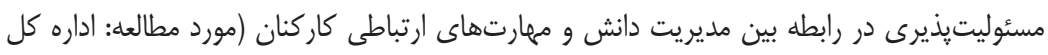

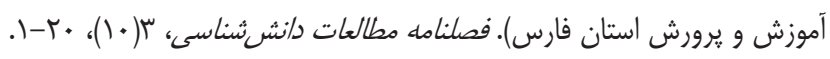

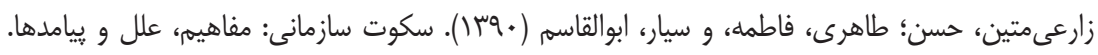

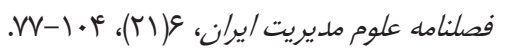

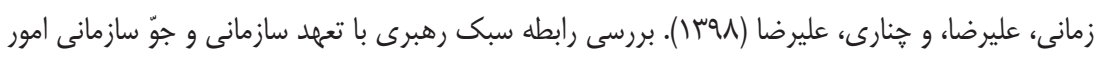

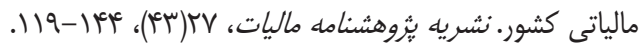




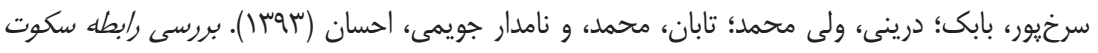

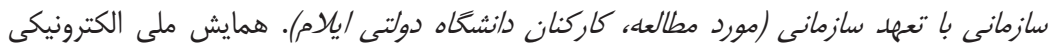

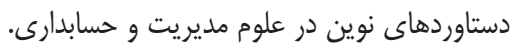

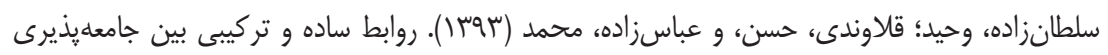

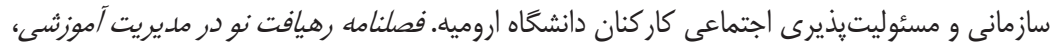
$19 V-19+19$ شجاعى، سامره (اوجا). بررسى سكوت سازمانى و راههاى برونرفت. ماهنامه علمى آمززشى تخصصى

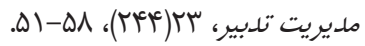

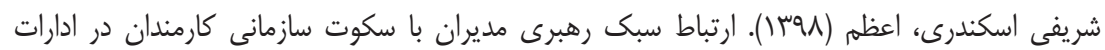

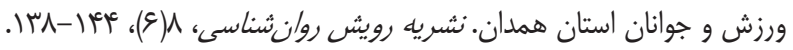

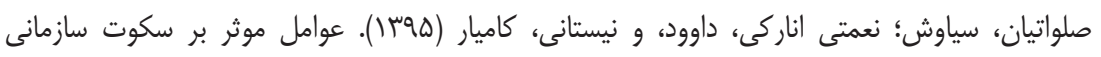

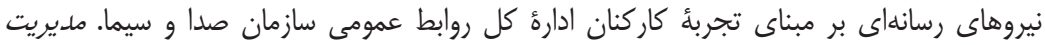

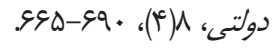

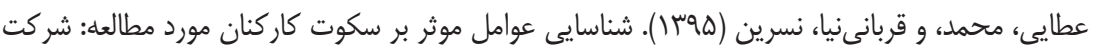

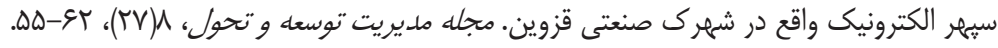

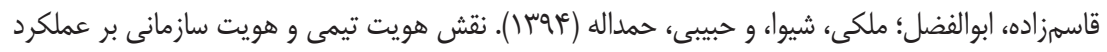

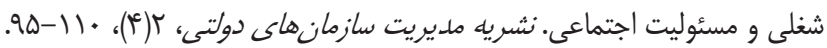

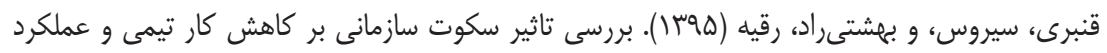

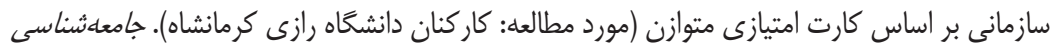

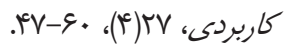

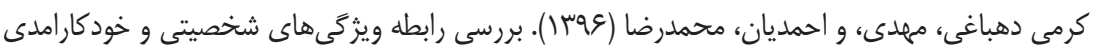

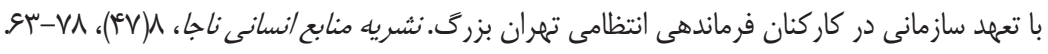

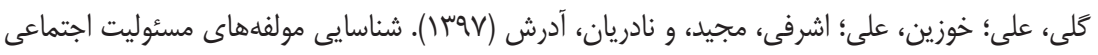

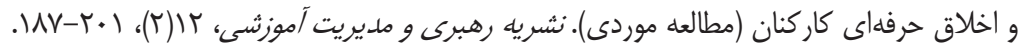

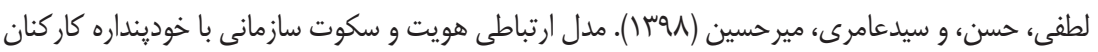

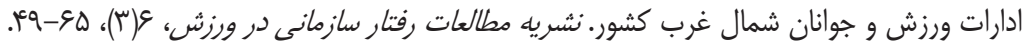

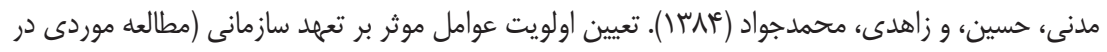

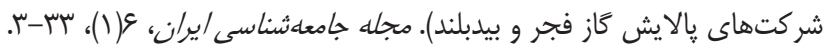

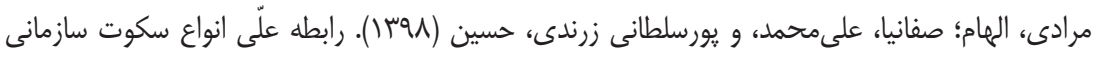

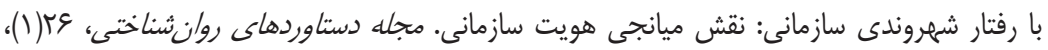

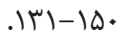
مهدى، رضا (بهوبا). تحليل وضعيت آموزش و بجسازى منابع انسانى بنكاهها از منظر مسئوليت اجتماعى.

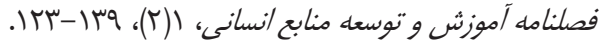




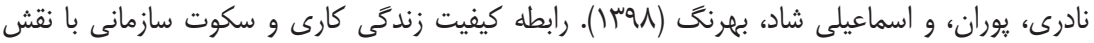

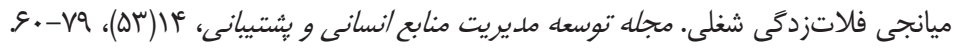

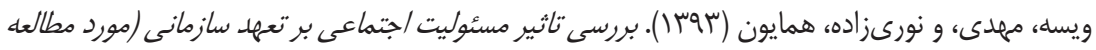

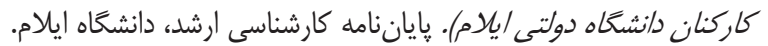

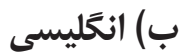

Allen, N. J., \& Meyer, J. P. (1990). The Measurement and Antecedents of Affective, Continuance and Normative Commitment to the Organization. Journal of Occupational Psychology, 63(1), 1-18.

Al-Rousan, M. A. M., Omoush, M. M., \& Ajloun, J. (2018). The Effect of Organizational Silence on Burnout: A Field Study on Workers at Jordanian Five Star Hotels. Journal of Management and Strategy, 9(3), 114-122.

Asrar-ul-Haq, M., Kuchinke, K. P., \& Iqbal, A. (2017). The Relationship between Corporate Social Responsibility, Job Satisfaction, and Organizational Commitment: Case of Pakistani Higher Education. Journal of Cleaner Production, 142(1), 2352-2363.

Brammer, S., Millington, A., \& Rayton, B. (2007). The Contribution of Corporate Social Responsibility to Organizational Commitment. The International Journal of Human Resource Management, 18(10), 1701-1719.

Brinsfield, C. T. (2013). Employee Silence Motives: Investigation of Dimensionality and Development of Measures. Journal of Organizational Behavior, 34(5), 671-697.

Brinsfield, C. T., Edwards, M. S., \& Greenberg, J. (2009). Voice and Silence in Organizations: Historical Review and Current Conceptualizations. Voice and Silence in Organizations (Vol. 1).

Carroll, A. B. (1991). The Pyramid of Corporate Social Responsibility: Toward the Moral Management of Organizational Stakeholders. Business Horizons, 34(4), 39-48.

Chou, S. Y., \& Chang, T. (2017). Employee Silence and Silence Antecedents: A Theoretical Classification. International Journal of Business Communication, 57(3), 401-426.

Collier, J., \& Esteban, R. (2007). Corporate Social Responsibility and Employee Commitment. Business Ethics: A European Review, 16(1), 19-33.

Cullen, J. B., Parboteeah, K. P., \& Victor, B. (2003). The Effects of Ethical Climates on Organizational Commitment: A two-Study Analysis. Journal 
of Business Ethics, 46(2), 127-141.

Liu, D., Wu, J., \& Ma, J.-c. (2009). Organizational Silence: A Survey on Employees Working in a Telecommunication Company. Paper Presented at the 2009 International Conference on Computers \& Industrial Engineering.

Demirtas, Z. (2018). The Relationships between Organizational Values, Job Satisfaction, Organizational Silence and Affective Commitment. Online Submission, 4(11), 108-125.

Deniz, N., Noyan, A., \& Ertosun, Ö. G. (2013). The Relationship between Employee Silence and Organizational Commitment in a Private Healthcare Company. Procedia-Social and Behavioral Sciences, 99(1), 691-700.

Detert, J. R., \& Burris, E. R. (2007). Leadership Behavior and Employee Voice: Is the Door Really Open? Academy of Management Journal, 50(4), 869-884. Donaghey, J., Cullinane, N., Dundon, T., \& Wilkinson, A. (2011). Reconceptualising Employee Silence: Problems and Prognosis. Work, Employment and Society, 25(1), 51-67.

Erdogdu, M. (2018). Effect of Organizational Justice Behaviors on Organizational Silence and Cynicism: A Research on Academics from Schools of Physical Education and Sports. Universal Journal of Educational Research, 6(4), 733-741.

Fast, N. J., Burris, E. R., \& Bartel, C. A. (2014). Managing to Stay in the Dark: Managerial Self-Efficacy, Ego Defensiveness, and the Aversion to Employee Voice. Academy of Management Journal, 57(4), 1013-1034.

Ferris, D. L., Brown, D. J., Berry, J. W., \& Lian, H. (2008). The Development and Validation of the Workplace Ostracism Scale. Journal of Applied Psychology, 93(6), 1348-1366.

Gencer, M., Tok, T. N., \& Ordu, A. (2018). The Effect of Power Base Games on Organizational Silence and Organizational Socialization. Universal Journal of Educational Research, 6(7), 1407-1423.

Gkorezis, P., Panagiotou, M., \& Theodorou, M. (2016). Workplace Ostracism and Employee Silence in Nursing: The Mediating Role of Organizational Identification. Journal of Advanced Nursing, 72(10), 2381-2388.

Gong, Y., Chang, S., \& Cheung, S. Y. (2010). High Performance Work System and Collective OCB: A Collective Social Exchange Perspective. Human Resource Management Journal, 20(2), 119-137.

Gunlu, E., Aksarayli, M., \& Perçin, N. Ş. (2010). Job Satisfaction and Organizational Commitment of Hotel Managers in Turkey. International Journal of Contemporary Hospitality Management, 22(5), 693-717.

Schulz-Hardt, S., Thurow-Kröning, B., \& Frey, D. (2009). Preference-Based Escalation: A New Interpretation for the Responsibility Effect in Escalating 
Commitment and Entrapment. Organizational Behavior and Human Decision Processes, 108(2), 175-186.

Hitlan, R. T., \& Noel, J. (2009). The Influence of Workplace Exclusion and Personality on Counterproductive Work Behaviours: An Interactionist Perspective. European Journal of Work and Organizational Psychology, 18(4), 477-502.

Jabbour, C. J. C., Sarkis, J., de Sousa Jabbour, A. B. L., Renwick, D. W. S., Singh, S. K., Grebinevych, O., . . Godinho Filho, M. (2019). Who Is in Charge? A Review and a Research Agenda on the 'Human Side' of the Circular Economy. Journal of Cleaner Production, 222(1), 793-801.

Kang, M., Yang, M. G. M., Park, Y., \& Huo, B. (2018). Supply Chain Integration and its Impact on Sustainability. Industrial Management \& Data Systems, 118(9), 1749-1765.

Karaca, H. (2013). An Exploratory Study on the Impact of Organizational Silence in Hierarchical Organizations: Turkish National Police Case. European Scientific Journal, 9(23), 38-50.

Kim, J. S., Song, H. J., \& Lee, C.-K. (2016). Effects of Corporate Social Responsibility and Internal Marketing on Organizational Commitment and Turnover Intentions. International Journal of Hospitality Management, 55(1), 25-32.

Kish-Gephart, J. J., Detert, J. R., Treviño, L. K., \& Edmondson, A. C. (2009). Silenced by Fear: The Nature, Sources, and Consequences of Fear at Work. Research in Organizational Behavior, 29(1), 163-193.

Knoll, M., \& Van Dick, R. (2013). Do I Hear the Whistle...? A First Attempt to Measure Four Forms of Employee Silence and Their Correlates. Journal of Business Ethics, 113(2), 349-362.

Leung, A. S., Wu, L., Chen, Y., \& Young, M. N. (2011). The Impact of Workplace Ostracism in Service Organizations. International Journal of Hospitality Management, 30(4), 836-844.

Lustenberger, D. E., \& Jagacinski, C. M. (2010). Exploring the Effects of Ostracism on Performance and Intrinsic Motivation. Human Performance, 23(4), 283-304.

Panahi, B., Veiseh, S., Divkhar, S., \& Kamari, F. (2012). An Empirical Analysis on Influencing Factors on Organizational Silence and its Relationship with Employee's Organizational Commitment. Management Science Letters, 2(3), 735-744.

Perkins, D. (2014). Conceptualizing Defensive Silence in Project-Manager -to-Project-Sponsor Communication. Leadership \& Organization 
Development Journal, 35(1), 2-19.

Perlow, L. A., \& Repenning, N. P. (2009). The Dynamics of Silencing Conflict. Research in Organizational Behavior, 29(1), 195-223.

Peterson, D. K. (2004). The Relationship between Perceptions of Corporate Citizenship and Organizational Commitment. Business \& Society, 43(3), 296-319.

Pinder, C. C., \& Harlos, K. P. (2001). Employee Silence: Quiescence and Acquiescence as Responses to Perceived Injustice. Research in Personnel and Human Resources Management, 20(1), 331-370.

Pohjola, M. (2001). Information Technology, Productivity, and Economic Growth: International Evidence and Implications for Economic Development: Oxford University Press.

Premeaux, S. (2009). The Link between Management Behavior and Ethical Philosophy in the Wake of the Enron Convictions. Journal of Business Ethics, 85(1), 13-25.

Schwepker Jr, C. H. (2001). Ethical Climate's Relationship to Job Satisfaction, Organizational Commitment, and Turnover Intention in the Salesforce. Journal of Business Research, 54(1), 39-52.

Spanuth, T., \& Wald, A. (2017). Understanding the Antecedents of Organizational Commitment in the Context of Temporary Organizations: An Empirical Study. Scandinavian Journal of Management, 33(3), 129-138.

Tan, H., Wang, H., Chen, L., \& Ren, H. (2012). Empirical Analysis on Contribution Share of Safety Investment to Economic Growth: A Case Study of Chinese Mining Industry. Safety Science, 50(7), 1472-1479.

Dyne, L. V., Ang, S., \& Botero, I. C. (2003). Conceptualizing Employee Silence and Employee Voice as Multidimensional Constructs. Journal of Management Studies, 40(6), 1359-1392.

Wu, C.-M., \& Chen, T.-J. (2018). Collective Psychological Capital: Linking Shared Leadership, Organizational Commitment, and Creativity. International Journal of Hospitality Management, 74(1), 75-84.

Yeh, L.-T., Tseng, M.-L., \& Lim, M. K. (2020). Assessing the Carry-Over Effects of Both Human Capital and Organizational Forgetting on Sustainability Performance Using Dynamic Data Envelopment Analysis. Journal of Cleaner Production, 250(1), 119584.

Zhao, H., Peng, Z., \& Sheard, G. (2013). Workplace Ostracism and Hospitality Employees' Counterproductive Work Behaviors: The Joint Moderating Effects of Proactive Personality and Political Skill. International Journal of Hospitality Management, 33(1), 219-227. 